\title{
Religious symbolism of the Palm Branch in the Greco-Roman Tombs of Egypt
}

\author{
Wahid Omran \\ Lecturer in Tourist Guidance Dep., Faculty of Tourism and Hotels, Fayoum University
}

\section{The palm branch in the Pharaonic period}

The palm played an important role in both ancient Egyptian ordinary life and funerary customs. It served as the place where the ancient Egyptians can sit under to enjoy the shadow and the cool air. The deceased also was depicted in prostration-attitude on the ground, drink water from the roots of the palm (pl.1). ${ }^{(1)}$ The water is protruding whether from date palm tree, dom palm, acacia palm, or Sycamore palm tree for giving life to the deceased. ${ }^{(2)}$ Acacia tree is mainly associated with Horus, ${ }^{(3)}$ while the Dom tree is associated with Min as a symbol of fertility. ${ }^{(4)}$ Depicting the deceased under the tree goddess is illustrated in chapter 59 of the Book of the Dead for breathing air and having power over water by the tree's goddess. ${ }^{(5)}$

In the ancient Egyptian mythology, the palm also was a symbol of time, which was interpreted in the funerary texts in the temples as a symbol of the king's funeral long life. It was presented by the gods for the king upon the temples' walls; they are holding the Isched-palm in their hands, which is often combined with the hfn sign of the frog $(100,000)$, and the shen ring $(10,000,000)$. The date palm rib was mainly a gift of god Thot as (lord of time) to the kings for a guarantee for a long life and millions of years for the king, ${ }^{(6)}$ and how the god holds the palm-branch as a symbol of long life.

The pre dynastic Egypt has revealed that the palm branch was connected with funerary customs, it was included in the offerings for the dead, and was laid on the mummy's chest. ${ }^{\text {(7) }}$ Moreover, it was put inside the tombs to secure a permanent youthful life for the deceased. The deceased also appeared with the palm fronds in his tomb to overcome death. In addition, it was depicted upon the deceased's mummy coffins (pls. 2 a, b). ${ }^{(8)}$

Since the $19^{\text {th }}$ dynasty till the Roman period; palm branches were depicted in the tombs as a guarantee for the deceased for another life in the netherworld. Therefore, in the Greco- Roman period the deceased was integrated to show the complete palm tree in his tomb, or to show palm fronds in his hands to securing his rebirth, re-verification and a long after life. ${ }^{(9)}$

In the Pharaonic period, palm was also associated with many other gods; as Hathor, Thoeris, ${ }^{(10)}$ Atumn, ${ }^{(11)}$ and Re. ${ }^{(12)}$ The coffin texts (CT 325) mentioned the sun-god was depicted in the form of a palm, and so, the deceased wishes to imitate the sun god, and to be fed with palm $(\mathrm{CT} 186,202) .{ }^{(13)}$ The date palm symbolized the location where the youthful morning sun roses and reborn again in the sacred grove at Buto. ${ }^{(14)}$

The palm branch was either associated with the heb-sed festivals of the kings as the depiction of king Amenemhat I in his pyramid temple at Lisht. ${ }^{(15)}$ Its connection with rebirth, led to its employment in festively purpose inside the mammisi of the Greco- Roman period. Of these, the mammisi of Edfu and Dendera; where several rows of goddesses are represented holding palm ribs. ${ }^{(\mathbf{1 6})}$ Therefore, it was used in the funerary processions of the deceased in his tomb, as a kind of processional symbol. ${ }^{(17)}$

The tree's goddess was a common representation in temples, tombs, stele, sarcophagi ...etc. The Pyramid text 574 mentioned the importance of the sycamore tree for the deceased "O one, Sycamore, which the gods protect, and the gods of the netherworld stand under it" ${ }^{(18)}$, the deceased hope to be full protected under the sycamore, as Osiris had done. ${ }^{(19)}$

Various goddesses had acted as tree goddess. The well-known goddess Nut is frequently depicted up on the tombs' walls as the goddess of the tree. She is the goddess of the sky, and was responsible for receiving the deceased in the sky to give him water as a donor for life again for the deceased in his afterlife. The early representation of the tree goddess is attributed to the $5^{\text {th }}$ dynasty, in tombs of Ptahhotep and Akhethotep. ${ }^{(20)}$

Nut was depicted as the goddess of the tree; not only up on the tombs' walls, but either up on the stelae, on mummy coffins, on sarcophagi, on ushabti boxes, and on mythological papyri. ${ }^{(21)}$ There are more representations of Nut as goddess of the tree inside the tombs of Late Period, as the tomb of Si-Amon in Siwa from the $3^{\text {rd }}$ century BC. There is a representation of goddess Nut under the Sycamore tree while giving water and life to the deceased, the Siwans refer to the tree as olives tree, which was abundant there. ${ }^{(22)}$

Hathor also appeared as a tree's goddess. The sycamore tree "nht" was one of the famous attributes for Hathor as "Mistress of the Sycamore tree". This has been mentioned in chapter 52 A and B (Papyrus of Nu, BM. 10477) as "I will eat under the sycamore of Hathor". ${ }^{(23)}$ Hathor as a goddess of the tree is depicted up on coffin of Ta-Bak-Chons; she is pouring water to the female-deceased under the sycamore tree. ${ }^{(24)}$ In other cases; Hathor was depicted with the date Palm tree, as she was described also as "Mistress of the Date Plame". ${ }^{(25)}$ Isis also played the same role; that the young son Tuhtmosis III is depicted suckling milk from the sycamore tree in his tomb. ${ }^{(26)}$ 


\section{The palm branch in the Greco- Roman period}

The palm branch in the Greco-Roman period associated with many Egyptian and Greek deities such as Osiris, Serapis, Isis, Harpocrates, Thot, Asklepios, Tyche and Hygieia. ${ }^{(27)}$ Palm branches are associated with gods of the Osirian's cycle. A lamp of Toronto depicted Serapis enthroned on a frond of palm leaves, ${ }^{(28)}$ or holding a palm branch on coins. ${ }^{(29)}$ palm is closely attendant between the Isiac cycle with Anubis; a Greek papyrus of the Roman period, now in Leiden, describe Anubis as "I am the tree which is called Palm (bais), I'm the efflux of the blood of the palm branches from the tomb of the great one (i.e. Osiris). ${ }^{(30)}$ It was one of the main offerings for the god during the Khoiak festival. ${ }^{(31)}$

Thot's association with date palm since the Pharaonic period as a god of writing, led him to appear while holding the palm branch during the Greco-Roman period as an attribute in his function as "Lord of Time" and "Reckoner of the Years". Terracotta from Roman Egypt depicts him in the form of a baboon, is holding a palm branch (pl.3). ${ }^{(32)}$ Furthermore, it appeared in human figure upon the mammisi of the Greco- Roman temples inscribed on his attributed Isched- palm leaf a long life for the child Horus, son of Isis. ${ }^{(33)}$

The close connection between Thot and Hermes in the Greco- Roman period, and the relation between Anubis and Hermes as funerary gods in one character as Hermanoubis, gave Thot, Anubis and Hermes the appearance with the palm branch. Coins from the Ptolemaic period, the reign of Ptolemy II and III depicted Hermes with the palm branch, while terra-cottas from the $1^{\text {st }}$ century A.D depicted him in the same figure. ${ }^{(34)}$ It was a promise of future life that he carried the palm branch. ${ }^{(35)}$ Schrreiber suggested the bronze-statue which depicted Alexander the Great as AlexanderHermes (pl.4 ) while holding the caduceus in his right hand, and the palm branch in his left, that the palm branch by Alexander is not a symbol of victory, but as a token of time-reckoning derived from god Thot. ${ }^{(36)}$

Likewise, Hermanoubis depicted on the Alexandrian coins with the caduceus and the palm branch while a dog is crouching on the ground (pl. 5). ${ }^{(37)}$ Pietschmann assumed the Alexandrian Hermanoubis caduceus and the palm branch are substitutes of the Osirian insignia flail and crook. ${ }^{(38)}$ Hermanoubis often appears in bust form, as in a coin of Hadrian, which shows a palm-branch (or leaf) upright in front of the god ${ }^{(39)}$ While the marble statue of Hermanoubis with the palm branch of the temple of Ras el-Soda is the best preserved example (pl.6). ${ }^{(40)}$

Furthermore, during the Greco- Roman period, the palm branch was associated with astrology, what is called "palm of astrology", a hieroglyphic document (6. Year B.C) from Canopus refers to an Egyptian religious procession by a priest, is known as a "horoscops". "(41) Some scholars tried to connect between the astrological palm branch and Anubis, while others denied this assumption. ${ }^{(42)}$ Widman related the Horoskopi or Astrologoi function corresponds with the Egyptian priests as the hours observers, that the Horoskopi's function connected with a ritual ceremony, in which the priest is holding palm branch as a symbol of astronomy. The most preserved depiction of this function is in fresco in the Iseum of Pompeii. ${ }^{(43)}$

The palm as a symbol of revival and resurrection for the deceased in his afterlife in his tomb let it to connect with the Judgment's court of the deceased, as a symbol of positive result of the court as a good person. The palm as a symbol of the non-guilty deceased in the stage of the court is well-confirmed and illustrated on the Mummy-Coffin Berlin 22728; where the deceased is led by Anubis, who is turning his face towards Osiris. Here, Osiris is depicted sitting in his shrine, and the Devourer is crouching facing him. The deceased is depicted as a black mummy-skeleton with upraised arms, while his crop in the form of a palm tree, that palm branches are protruding from his crop (pl.7). Dieter Kurth suggested the figure of the deceased assume positive judgment decree for him, so enables him to get into the stage of rebirth and resurrection in the Netherworld. ${ }^{(44)}$ Equally, new form of the numerous positive rebirthed deceased during their judgment courts, which was mentioned by Seeber; non-guilty deceased was depicted in the mummified figure of Osiris holding two feathers, squatting upon a bent stick, upon the crock, or to be either depicted in the form or the rebirthed $\mathrm{Ba}$ form. ${ }^{45)}$

The palm tree is a typical Egyptian motif for the Ancients. It was not grown in Greece at that time, and its existence outside Egypt was intended to evoke Egypt and one of its divine representatives, Isis or Serapis. ${ }^{(46)}$ Palm branch as a symbol of victory appeared in Egypt only during the Greco- Roman period, especially in the Roman period. A palm branch is painted on few Greek and demotic mummy labels as one of the religious symbols with the Ankhsign. ${ }^{(47)}$

Moreover, it appeared on the head of mummified crocodiles from Fayoum of the Roman period. The palm branch as a symbol of victory over death in the funerary customs of the deceased complete the same Pharaonic meaning of the palm leaf as a symbol of eternal life presented by gods to kings upon the Egyptian temples. While its appearance on the heads of the crocodiles regenerated through the rites of mummification and burial, as a symbol of regeneration (pl.8a, b). ${ }^{(48)}$

In the Roman period, the palm branch as a symbol of eternity and triumph over death is expressed. ${ }^{(49)}$ It was depicted upon many coffins in terracotta of the Roman period in the valley of the queens. ${ }^{(50)}$ In a funerary context the, palm branch denoted continuous life after death; it occurs thus on the breast of a mummy, or when it is carried in the funeral procession. The limestone bust of a young woman from Antinoupolis dated to $4^{\text {th }}$ century A.D, shows her holding a palm branch in her hand as a sign of eternity. ${ }^{(51)}$ 


\section{The palm branch as a gymnastic gift}

In Greek Mythology, the palm has both gymnastic and funerary symbol of victory "palma victrixor Palmae victrices". ${ }^{(52)}$ Moreover, the Greeks associated the date palm with their famous bird, the Phoenix, which is a long-lived bird that is cyclically regenerated or resurrected, associated with the sun. It obtains a new life by arising from the ashes of its predecessor. The Greeks believed date palms came originally from a Phoenicia. ${ }^{(53)}$

The symbolism of the palm as a victory sign derived from the Greek athletic games. Moreover, it is related to the Greek funerary concept, ${ }^{(54)}$ as well as the same funerary context in the Roman concept; ${ }^{(55)}$ a sarcophagus of a child, now in Latran, depicts an athletic competition on it, portrays two boxers and two wrestlers. Furthermore, the referee holds a palm branch in his hand as a ward or prize to the victorious champion (pl. 9). ${ }^{(56)}$

Another sarcophagus of a girl (Octavia Paulina), depicts both male and female children in a strife, with the presence of a figure of goddess Rome. While the valiant male champion is represented in the middle with the palm branch. ${ }^{(57)}$ Moreover, the palm branch was a sign of victory between the animals, a terracotta of an eagle from the Roman Egypt with a palm branch in its claws, and supervising a boxing match between a cat and a mouse. The palm branch will be presented to the winner (pl.10). ${ }^{(58)}$ The palm was considered a symbol of victory on death, also by the Romans, an altar at the Vatican, decorated with palm branches, represent two victorious figures reopening the door of the gate of Hades. ${ }^{(59)}$

During the Greco- Roman period, the palm was associated with the cavaliers as a sign of victory. It was one of the attributes of the Thracian god Heron, whose cult was known in Egypt, especially at Fayoum, ${ }^{(60)}$ and appeared as a cavalier upon his horse with his weapons. He was associated mainly with the Greek military mercenaries at Fayoum. The palm was one of the main attributes of the god, that the palm tree always appeared beside him and a serpent lies on or coils up the tree and drinks from a Patera that Heron offers. ${ }^{(61)}$

A wooden panel representation of Heron is now in the Egyptian Museum of Berlin, only the right half of a wooden panel, was found in a private hose from Tebtynis. It is about $41 / 25,5 \mathrm{~cm}$, and depicts Heron with his lance in his left arm. While the serpent is coiled around the palm tree,${ }^{(62)}$ probably, the god of the double axe was depicted on the panel's left side, which is now missing. ${ }^{(63)}$ Cairo University excavations between 1969-1970 in Karanis has uncovered a mural painting, now in a magazine in Giza. It depicts Heron accompanied with "black servant", on the left side, a person is holding a Dom-palm branch; he is most probably the god of the double axe(pl.11). ${ }^{(64)}$

\section{The palm branch and the inundation}

In Roman Alexandria, the palm branch was associated with the feast of the high flood. The feast was associated with the beginning of the flood, when the Nile level raised to 16 cubits, it was considered sufficient for a successful crop, when the flood reached the mark, this was rapidly announced throughout the country. Since 165-166 A.D, this event is signified on Alexandria coins by a female figure of the Semasia, a young woman on a galloping horse, holding a palm branch, and announces the height of the flood (pl.12). ${ }^{(65)}$

The relation between the Nile Inundation and the palm branch is well-illustrated in the Nile mosaic of Palestrina. It was dated between the $2^{\text {nd }}$ century B.C to the $1^{\text {st }}$ century A.D. The Nile mosaic themes became popular from the Hellenistic and Republican period houses and villas surrounding Pompeii. Its significance mainly attributed to Isis's cult there, ${ }^{(66)}$ as a kind of Aegyptiaca in Rome. ${ }^{(67)}$

The Nile mosaic of Palestrine, $50 \mathrm{~km}$ east of Rome, ${ }^{(68)}$ it shows Egyptian priests of Amon while carrying palm branches in a procession festival, linked with the new Nile water ${ }^{(69)}$ In the same Ptolemaic mosaic, there is either an inundation scene represent the ceremonies of the Khoiak festival and the inundation of Egypt. This shows a priestess of Isis carries a palm branch and holds out a "simpulum" to an officer accompanied with soldiers, who is raising a drinking horn or "rhyton", beside what is seems the tomb of Osiris. Possibly, the palm branch here is may be a sign that the flood has been successful. This was held by the figure of Semasia, and the officer here is receiving the sacred Nile water (pl. 13). ${ }^{(70)}$

The priestess of Isis here is acting the same role of Semasia in the Roman period to announcing the height of the flood. In the Hellenistic period, Isis was connected, beside Osiris, with the inundation flood, ${ }^{(71)}$ that is connected with inundation festivities, numbers of terracotta figurines representing Isis-Hathor- Aphrodite, holds drinking horn or drinking cup. She holds palm branch, which presumably indicates the triumph of the flood. These terracotta statuettes of Isis-Hathor-Aphrodite perfectly illustrate the licentious mood of the population at the time of inundation. ${ }^{(72)}$ The palm branch was used as offering, and may have been used in a ritual connected with the feast of inundation. ${ }^{(73)}$

Furthermore, palm branches were used in both Pharaonic and Greco-Roman periods for embellishments. Decorating the tombs with palm trees was an important scheme of embellishing the Pharaonic period as a kind of representing the traditional Egyptian gardens; such as the tombs of the treasurer "Sobek-hotep" at Thebes (TT 63) (pl. 14), of "Tjanefer" the priestess of Amun(TT 158) (pl. 15), ${ }^{(74)}$ and the garden of "Jnni" at Thebes Tomb Nr. 81. ${ }^{(75)}$ Moreover, palm branches decorated one of the Roman period temples in Fayoum on the occasion of a festival in Arsinoe. ${ }^{(76)}$ The palms also decorate the walls of the tombs of Anfusy and Petosiris of el-Mazzawaka. 


\section{Isis and the palm branch in the Hellenistic World}

In the Hellenistic world, Palm is closely associated with the cult of Isis outside Egypt. This is a kind of shimmering palm-leafs wreath connected with Isis cult, as a symbol for the worshipper and the deceased to be safety. It was worn by the priests of Isis during her festivals, and by her women adheres either. ${ }^{(77)}$ Furthermore, Isis may carries it herself (pl.18). ${ }^{(78)}$

The palm tree has a distinguished appearance at Corinth. It is connected with the cult of Demeter-Isis there. From the lower city of Corinth; three marble palm trees may have had such a topographic function, as may those depicted within enclosures on two Corinthians coins. A series of terracotta antefixes a roof dismantled in the central temple of Demeter at Korinth. These terracotta are unique, they are decorated with date palm with dropping palm branches, and two clusters of seedpods replaces the usual palmette, as a further example of syncretism between the cult of Isis and Demeter. ${ }^{(79)}$

Palm tree in Greek methodology has numerous meanings. It is a symbol of fertility, shown by Leto's giving birth one on Delos. The palm tree is either a common motif in the worship of Artemis. ${ }^{(80)}$ It is either connected -as mentioned- to the procession festivals of Isis; a priest carried a golden palm branch during the procession in honor of Isis at Kenchreai. ${ }^{(81)}$ The palm tree appeared in a fresco from Herculaneum (pl. 19), ${ }^{(82)}$ and a relief of Ariccia, depicting Isiac ceremony. ${ }^{(83)}$

The palm branch was a key element in the processional festival scenes of Isis in the Hellenistic period; at Cenchreae near Corinth. These scenes show the sailing of Isis's ships, where the symbols of Isis were hold by the chief priests of Isis. One of them is lifting up a gold-leafed palm branch, ${ }^{(84)}$ a "pastophoros" (priest) of Isis is depicted either on one of the columns of Isis Campense wearing the palm wreath and holding the Isiacsistrum in the right hand, and a palm branch in the left (pl.20 ). ${ }^{(85)}$ Another priest is depicted on column A of the Iseum Campense holding a palm branch faces Osiris statue. ${ }^{(86)}$

A similar branch is carried by the priest of Isis in an Isiac procession on a wooden board from a coffin, now in Hildesheim 2373. It dates back to the time of Domitian, and portrays four figures; the first is a priest of Isis holding a palm branch (pl. 21). ${ }^{(87)}$ Another priest of Isis is painted in the Iseum Pompeii with the palm branch. ${ }^{(88)} \mathrm{A}$ third one is depicted with a palm tree behind him (pl.22) ${ }^{(89)}$ Isis's followers at Tarsus also were portrayed with the Isis palmette symbol. ${ }^{(90)}$ palm trees are also flanking the central scene in the Isiac ritual frescos from Herculneum. ${ }^{(91)}$

\section{Anubis and the palm branch}

Other members of the Isiac cult cycle, whose cult reached Rome in the accompanying of Isis. Moreover, they appeared with palm branches in their hands. Anubis, the nephew of Isis and her cynocephalus guardian, the palm branch was an attribute of the Roman Anubis inside, ${ }^{(92)}$ and outside Egypt. ${ }^{(93)}$ He was depicted with the palm branch in statues, inscriptions, lamps, terra-cottas, amulets, coins and sarcophagi. ${ }^{(94)}$

Isis's priests with the mask of Anubis appeared in her processions at Rome with the palm branch as AnubisHermes or Hermanubis. Therefore, Anubis was depicted holding the caduceus and palm fronds, the main attributes of Hermes (pl. 23). ${ }^{(95)}$

Certainly Anubis, like Hermes, was a guide of souls in the sense that the process of embalming after death. Besides, he is shown leading the deceased, and taking him by the hand, and the god who has the keys of the gates of Hades. ${ }^{(96)}$ Since the Pharaonic period, the palm was one of the attributes of Anubis, as well-seen inside one of the tombs of the Queens' Valley (tomb nr. 40), the time of Rameses III, Anubis is depicted holding a green palm branch with his right hand (pl.24). ${ }^{(97)}$

Furthermore, the palm branch is carried by funerary genii in the tomb of Nakht-Min of the Ramesside period at Deir elMedina (pl.25). ${ }^{(98)}$ Ram-headed genii are either depicted carrying palm branches in their right hands in the tomb of Nefertary (pl.26). ${ }^{(99)}$

During the second and ninth hours of Amduat; gods holding an Ankh-sign in one hand, and a palm branch as palm-scepters in the other. According to the inscriptions; they are field-gods who cause all trees and plants to grow. ${ }^{(100)}$ Fragments of a sarcophagus of Deir el-Medina dates back to the Greco- Roman period shows the deceased on his bed, and flanked with two palm branches, and a big amphora was found there decorated with two palm branches. ${ }^{(101)}$ Palm branches decorate many of the Roman period lamps found in the Queens valley. ${ }^{(102)}$

One of the clearest depictions of Anubis with palm branch and caduceus of Hermes comes from the Iseum in Savaria, where the palm branch in the right upraised hand, while the Caduceus in the left one. ${ }^{(103)}$ Moreover, his silver statue from Salona in Dalmatia (the camp of Diocletian) depicted him with the latter two attributes. ${ }^{(104)}$ While a coin from Perinthus in Thrace depicts him only with the palm branch. ${ }^{(105)}$ In other cases Anubis appeared under the datepalm tree, as depicted on two mummy-portraits from the $1^{\text {st }}$ century B.C (pl. 27). ${ }^{(106)}$ Two marble statues were found at Antium (Anzio), beside Rome, depicts Anubis standing, and a palm tree trunk at the back (pl.28). ${ }^{(107)}$ Furthermore, The date-palm tree was depicted in front of Anubis on an Isiac altar from Guadix, north of Granada (pl. 29). ${ }^{(108)}$ 
Anubis sculpted on altars with palm branch and the situla of Isis. ${ }^{(109)}$ Another stela has depicted him with the palm branch and caduceus from the necropolis of Ostia. ${ }^{(110)}$ Anubis, with his mask of a jackal or a dog, also has the palm of victory in his hand. He thus symbolizes the victory of life over death, and leads the deceased to their resurrection by the palm branches in their hands, ${ }^{(11)}$ nor would Isis's procession or festival have been conducted in due form without an Anubis to march at the head with wand and palm, ${ }^{(112)}$ till the Christian period at Rome. ${ }^{(113)}$

Moreover, palm branch is associated with Harpocrates; a young child characterized with the sided-lock of childhood as Harpocrates holds a palm branch(pl. 30), ${ }^{(14)}$ or with Harpocrates himself in a wall-painting from the Iseum of Pompeii. ${ }^{(115)}$

\section{The palm branch in Jewish mythology}

The palm played the same role in the neighboring Nubia as a homeland for the palm. ${ }^{(116)}$ Date palm is either associated with the Jewish Mythology, known as Tamar. After the destruction of Jerusalem by Titus in 70 A.D, the Emperor Vespasian minted a coin showing a grieving woman seated under a date palm. This commemorated Rome's merciless retaking of the colony they called Palestrine. ${ }^{(117)}$

Palm branches have its festively and joy meaning. The Jewish "feast of Tabernacles" celebrated with palm branches tied together with myrtle and willow, which are held in the right hand. Roman coins showed an allegorical figure of joy (hilaritas) holding a palm leaf. ${ }^{(118)}$ The offering of palm leafs reflect a Roman custom, still in use in modern - day at Dakhla Oasis. ${ }^{(19)}$ Like elsewhere in Egypt, women used to bring palm fronds to the tombs of the deceased on days of religious festivals. ${ }^{(120)}$

\section{The palm in the Christian period}

A palm branch is still a sign of victory over death in the Christian context; a two palm branches ornamented cross is depicted in the tomb of Nebettaouy (tomb nr. 60) in the Valley of the Queens (pl. 16). ${ }^{(121)}$ It was connected with saint Onuphrius (Wnn-nfr), the Egyptian saint who lived in the Theban desert of the $4^{\text {th }}$ century A.D. He lived in the Theban desert, and for 60 years he ate and drank water from a palm tree. This legend is painted in fresco in the Nubian Cathedral of Faras. ${ }^{(122)}$

During the struggle between Paganism and Christianity, the palm was considered as a sign of victory of Christianity over the Paganism and the traditional religions. ${ }^{(123)}$ In the church of Saint Paul, for enthusiastic goal; the martyrs who fight death for their faith, will be awarded with "the crown of glory" and "palm of victory", and they will enter the paradise without the attendance of resurrection as "athletes of the Christ". (124) A Christian stele depicts a worshiper raising his arms between two palm branches (pl.17). ${ }^{(25)}$ Furthermore, the palm associated with one of the popular Coptic feasts, "the palm Sunday", where the Copts throng their churches from early morning carrying plaited palm leaves in crosses' shapes. ${ }^{(126)}$

\section{The palm scenes in the Greco-Roman tombs}

The palm appeared inside Egyptian tombs during the Greco- Roman period, either only for decoration. A kind of representations of the traditional Egyptian gardens, as was decorated before in the Pharaonic tombs. Other representations of the palm have funerary burial symbols for the deceased.

\section{Anfushy}

\section{Tomb nr.5 - Burial room 2 (Anfushy V.2)}

The most usual feature of this room is the painted decorations of trees with painted piers on the back wall above the funerary bed, and on the lateral wall above the funerary bed. A pair of date palm trees are depicted as decorations in the tomb with their dates on the back wall of the chamber, and flanked by deciduous trees. The trees show a lively spirit and an observation of nature both in their rendering and the choice of coloration. The palms' fronds are drawn in green flecked with yellow touches, while its fruits are hanging down from two branches at the trunk's top. It is painted in red or yellow, indicating a difference in type or in maturation between the dates of one tree and another (pl. 31). ${ }^{(127)}$

\section{Tomb nr.5- Burial room 5 (Anfushy V.5)}

The main burial room of the tomb, combines Greek and Egyptian decorative schemes, and holds another exceptional loculus. On the interior of the large loculus in Room 5; the same date palm trees and deciduous trees are similar to those in chamber nr. 2 of the tomb, with the addition of shrubs and aquatic plants. The crowning band over the trees shows the practice arrangement of the flora, as a traditional Egyptian garden painting of various plants and trees as the date palm, grape olive, and barely trees, with the existence of the fertility deities of the river. ${ }^{(128)}$ The trees are set on a single ground line against a neutral ground. ${ }^{(129)}$

The Egyptian elements in the Anfushy and Ras El-Tin tombs have led to the suggestion that their decoration reflects the interest of the native Egyptian population of Pharaos Island as the Wardian tomb. ${ }^{(130)}$ Therefore, the tomb owners paid attention to representing the Egyptian trees in their tombs. The symbolism of depicting palm trees in the graves most probably related to vegetation and fertility in relation to renewing the deceased's life. The palm branches 
are shading and protecting the tomb. Osiris's sarcophagus is enveloped by a tree, the sarcophagus that is being here identified with Osiris, ${ }^{(131)}$ thus the deceased imitated his tomb to be protected by trees, especially the palm ones.

Savvopoulos suggested the representations of various trees of room 2 at Anfushy $\mathrm{V}$ tomb. These are interrupted by some architectural elements in the form of doorframes, as holding the vaulted ceiling of the room, which is decorated with a tapestry-like design. Probably, wall and ceiling decorations of the room imitate a kiosk in the middle of a gardenmetaphorically representing the Abaton, the tomb of Osiris, ${ }^{(132)}$ that palm-leaves were laid on the 365 altars surrounding Osiris's tomb in theAbaton. ${ }^{(133)}$ The palm representation had become a promise of eternity for the deceased, and in Egypt, it was connected especially to the circle of Osiris. ${ }^{(134)}$

The Alexandrian influence of the Egyptian trees with special appearance of palm trees had appeared at Syria and Coela Syria, like palm's appearance in the Marisa Tomb $1 .^{(135)}$ Moreover, the depiction of a garden with Egyptian trees is depicted inside many Roman Casas such as Casa del Fruttetoat Rome, ${ }^{(136)}$ fresco with Nilotic landscape of the Casa deiCei at Pompeii. ${ }^{(137)}$ Another fresco is in the garden of the Casa di Apolline at Pompeii, ${ }^{(138)}$ in the Casa deiPigmei at Pompeii (pl.32), ${ }^{(139)}$ and in an inundation fresco scene in casa delle Amazzoni at Pompeii (pl.33). ${ }^{(140)}$

\section{The Stagni Tomb}

\section{- The niche- the back wall of the tomb}

Inside the aedicule, a nude- female figure stands frontally. This was identified Venit as isis- Aphrodite, wears a diadem of a central yellow disc surrounded by green "Palmette"-flanked green basileions, in which the "palmette" assume the form of rays, in the form of a radiate crown. She raises her hands at the level of her breasts, her elbow out of either side and she holds a staff, which terminates in a lotus bud, passes over her right shoulder (pl.34). ${ }^{(141)}$

\section{Tigrain}

\section{The back-wall of the central niche of the burial chamber}

Two female figures are holding palm fronds in their hands; they flanking the deceased mummy upon his bier, while a winged solar disc hover over head extending a garland in its claws. The mummy encased as is normal in the Roman period; interesting diagonal lines, with empty squares within the rectangles with a green wash, supported by Roman headrest with a bird's head (pl.35). ${ }^{(142)}$ The scene is certainly imitating the resurrection process of god Osiris. However, the mummy is for the deceased, not for Osiris himself, ${ }^{(143)}$ as Adriani, ${ }^{(144)}$ and Brenk suggested. ${ }^{(145)}$

At the foot of the bier, the winged female stands in the traditional Egyptian pose with a frontal torso. She is garbed in a scale -patterned dress terminates at her calf with fringes, and has tight elbow-length sleeves. she wears a headdress topped with the protective-uraeus symbol and floral arrangement (a lotus). ${ }^{(146)}$ The female figure at the top of the bier is similar to the other female figure, but holding the two green palm frond with clasping hands upon her chest. However, the other figure was as been depicted with outstretching hands, ${ }^{(147)}$ which extend the palm branches to the deceased, so enables him to get his victory over death and rebirth again in the afterworld.

The identification of the two female figures is a problematic case, despite their lack of familiar attributes of Isis and Nephtys. Adriani identified them as Isis and Nephtys. ${ }^{(148)}$ Venit preferred the female figures are intended as epiphanies of the goddesses or as priestess avatars for the goddesses. ${ }^{(149)}$ They are meant both stylistically and ichnographically to replicate their ancient Egyptian counterparts, this is difficult to determine, despite their lack of attributes. In other occasions, Venit suggested them as Isis and Nephtys, ${ }^{(150)}$ since they are often spread their wings to protect the dead. ${ }^{(151)}$ Wallert ${ }^{(152)}$ and Dils, ${ }^{(153)}$ suggested them as Isis and Nephtys, while Brenk suggested they are the traditional Nephtys and (a pteroform) Isis. ${ }^{(154)}$

The spread of the cult of Isis and her overcoming and controlling on the funerary practices inside the Roman tombs of Egypt, in addition to the familiar task of Isis and Nephtys as guardians for the deceased's mummy in the tomb. Besides, their appearance with the palm branches, which was a main attribute for the cult of Isis inside and outside Egypt. These notes led the researcher to suppose the two female figures depict Isis and Nephtys, who are acting their familiar role as guardians of the deceased, who supposed to be became Osiris NN in his tomb.

\section{The rear wall of the burial chamber's right niche}

A male figure garbed in tunic and leggings with a crosshatched pattern and wearing a helmet takes the form of a nemes head cloth. He is shown in right profile kneeling on his left knee, and holds with each hand two green palm branches. Furthermore, he extends them to the standing goddess or priestess in front of him, who is depicted with a diadem fronted by a uraeus, and a knotted garment upon her chest. ${ }^{(15)}$ She is offering him what may be sheaves of golden grain (pl. 36) ${ }^{(156)}$ which is mainly associated with Isis from the $4^{\text {th }}$ century BC. ${ }^{(157)}$ While a figure with a censor is following the kneeling male figure.

Diodorus associated her with the discovery of wheat; and in her guise as Isis- Thermouthis, who is often depicted with ears of wheat. ${ }^{(158)}$ Venit suggested Isis was the most important female deity in Alexandria, as a stategoddess. ${ }^{(159)}$ The decorations of the Tigrain tomb permit the possibility for the mysteries of Isis were also practiced 
inside the tombs of Alexandria -or near- during the Roman period, ${ }^{(160)}$ where he argued that tombs in the Chora preserve a visual evidence for Isiac mysteries as well. ${ }^{(161)}$

\section{The rear wall of the burial chamber's left niche}

The deceased in frontal view wearing a winged, nemes- headdress. He is clasping his two hands on his torso, by which he catches two green palm fronds. Moreover, he is flanked by two male figures on both sides; two jackals sit attentively at the frontal male's feet (pl.37). ${ }^{(162)}$ The male figure in the left niche is completely differ from the right side one. The the left niche's scene shows the symbolic rebirth of the initiate, as he threw off his mummy wrappings and emerges nude ${ }^{(163)}$

\section{Tuna el-Gebel}

\section{The eastern side of the northern wall of the naos- Tomb of Petosiris}

Nut as a palm sycamore tree goddess is giving water to the parents of Petosiris, who are seated on a chair, and receiving water with their right hands. ${ }^{(164)}$

\section{The lower register of the east wall of the antechamber of House $\mathrm{Nr} . \mathbf{2 0}^{(165)}$}

Isis is depicted in the form of a bird with a palm branch and Ankh-sign between its claws, and flying up on a lion's bed with the mummy of the deceased upon it. While Isis and Nephtys are on both sides of the bed (pl.38). ${ }^{(166)}$

The appearance of Isis as a falcon is attested on the funerary boat's bow, which ferries the dead to the west. She and Nephtys are "Two Kites", who bewail the dead, and appear as wailing women close to the deceased's body. Variety showed Isis as a falcon at the prow or at the stern of the sacred boat. ${ }^{(167)}$ She got pregnant from Osiris in the form of a falcon, flying as a falcon, and using her magical power upon the mummified body of Osiris.

\section{The western wall of Room 2 of House nr 21}

A mourning ceremony of the deceased, that goddess Nut is sitting on the ground, while the deceased's mummy is upon her lap. A falcon is flying upon the deceased's mummy with a palm stem between its claws. Anubis is sacrificing on an altar with his right hand, while leading Isis with his left hand, and Nephtys behind her, and both are in adoration attitude (pl.39). ${ }^{(168)}$

\section{The upper register of the southern wall of Room 1 of House nr.21}

Upon the entry door to Room 2, the Abydos-fetish was erected by two ram headed-gods. Horus and Isis on the right side, while Anubis and Nephtys are on the left, and adoring the fetish. Two mummified- figures on both sides of the whole scene, Isis and Nephtys are holding the palm ribs or the palm branch-scepter in their hands (pl.40). ${ }^{(169)}$

\section{Dakhla Oasis}

\section{The eastern wall of Petubastis's tomb}

The palm tree goddess is pouring water with ahst-vessel in her left hand on the ground, where Petubastis is seated before her inside a canopy. While a priest is making libation with his right hand, burning incense with his left hand, and an offering table is behind (pl. 41). ${ }^{(170)}$

\section{The lower register of the northern wall of Petubastis's tomb}

The palm tree goddess is pouring water with hst-vessels to Petubastis, who is seated upon a chair in a canopy, and Meskhenet the goddess of birth, is shown behind (pl. 42). ${ }^{(171)}$ The appearance of goddess Meskhenet behind Petubastis emphasizes the idea of rebirth, which was attributed to the tree goddess, who gives water to the deceased to secure him the life in the netherworld.

\section{The upper register of the northern wall of Petubastis's tomb}

This representation of the date palm tree goddess is a mazing and unique, it depicts the tree goddess in the middle of the judgment court of Petubastis. It appeared between the judgment's scale, where Anubis and Horus are under it, and the figure of god Horus, is depicted behind.

The date palm goddess representation is almost damaged; the branches of the tree are in red, while its leaves are in green. This refers to a date palm tree, a crouching figure of a child on a black saucer seat, with upraised arms to receive water from the palm. While two opposite ba- birds are upon the palm's uppermost. The front one is badly damaged, their bodies and heads are red, and they are depicted with the upraised arms, in the same attitude of the child for receiving water from the palm (pl. 43). ${ }^{(172)}$

\section{The southern half of the western wall of room 1 - Tomb of Petosiris}

A Judgment's scene; it depicts Thot, with the head of an Ibis and atef crown. He is registering the result of the judgment of the deceased upon a palm branch (pl.44). ${ }^{(173)}$ 


\section{The southern half of the western wall of room 2-Tomb of Petosiris}

An Egyptian garden is decorated on the wall's lower register. It combines a palm tree with date, in addition to grape and olive trees, barley and lotus flowers, with the existence of Hapy god and Sekhet-goddess, while carrying the offerings (pl. 45). ${ }^{\text {(174) }}$

Naphtali Baum suggested the tree, which was described by Osing with a kind of suspicion in the olive tree. However, it is the dump palm tree, its twisted high and solid trunk, is divided into three large branches; each one ends with heavily hemispherical crown, with green leaves. ${ }^{(175)}$

Though the tomb of Petubastis contains many representations of the palm tree goddess as a donor of water for the deceased to secure his birth again in his netherworld. This is missing in the tomb of Petosiris; there are no depictions of the palm tree goddess in the tomb, though both of Petubastis and Petosiris tombs are located in the same necropolis, and dated back to the $1^{\text {st }}$ century AD. The missing of the palm tree goddess inside the tomb of Petosiris was substituted only by the representation of Isis in her normal figure as donor of water to the deceased's Ba from hst-vessel (pl. 46). ${ }^{(176)}$ Perhaps the numerous representations of the palm tree goddess in Petubastis's tomb is mainly attributed to Isis. Isis here is assimilated with goddess T3j3dt or Tau", the goddess of water, which is depicted on the Mummy-Coffin of Moskau "I gives water to the deceased". (177)

Venit astonished that Isis played a minor role in both tombs of Petubastis and Petosiris at el-Mazawaka. Though she played a great role in the Greco- Roman tombs of Egypt. ${ }^{(178)}$ Osiris was the principal figure in the tombs of Roman Dakhla, while she played a subordinate role. She was neither attested on a single piece from cartonnage from Dakhla, nor included on the cartonnage recovered at Bahariya. ${ }^{(179)}$

\section{Douch- Tomb nr 20}

Inside the tomb, two winged victorious female figures are adorning the anterior face of a linen tunic. Both of them are holding palm branches; one in her right hand, while the other figure holds it in her left (pl.47). ${ }^{(180)}$

\section{Siwa}

\section{Tomb of Si-Amon- the western wall}

Goddess Nut is giving water under a sycamore tree. The tomb owner stands before her, and presents offerings placed on a table, and covered with a flower banquet (pl.48). ${ }^{(181)}$

\section{Akhmim}

\section{The lower register of the eastern wall's right side-the antechamber of Tomb Von Bissing $1897^{(182)}$}

A male figure is wearing a traditional kilt, though with a fringed edge. It stands in traditional Egyptian stance and holds a libation vessel in his lowered left hand, and a palm branch in his upraised right. Behind, is a naos cut off by the leafy tree in the corner (pl. 49). ${ }^{(183)}$

\section{The left wall of the eastern wall's entrance - of the burial chamber of Tomb IV ${ }^{(184)}$}

The southern wall has two scenes in two sections; the first one depicts Osiris sits on a throne under a canopy or a tent. Behind him, is a winged goddess, may be Isis. Further left is the deceased dressed in a white Roman garment. Before him, Horus and a lioness head goddess, both are holding palm branches, pieces of clothes, and libation vases in their hands (pl.50). ${ }^{(185)}$

\section{The back wall- the first niche of the burial chamber- Tomb IV}

The back wall of the niche contains three scenes; the middle scene depicts god Osiris guarded by Nephtys on the left side, and Isis on the right side. Behind Nephtys is a deity making libation with his left hand up on an altar. The water is running in one ray. Behind him is a figure, may be a priest up on his head. He is making libation and burning incense. To the right of Isis, is a damaged figure of Anubis holding a piece of cloth and a palm rib, and behind, Horus is either holding the same piece of cloth and palm rib (pl. 51). ${ }^{(186)}$

\section{The Left Wall of the burial chamber of Tomb IV}

There is an amazing scene, it depicts a damaged figure of the tree goddess. She is pouring water from a libation's vase, pouring up on an offering table. Instantly, it is completely damaged, only remains of a flower and of the table legs still extant. The deceased is receiving water from the goddess. ${ }^{(187)}$ The tree goddess is depicted in the judgment's court of the deceased, she is standing between the scale, with Anubis and Horus under it, besides the upraised figure of the deceased.

\section{The Northern Wall- The lower register}

The lower register depicts a damaged figure of the tree goddess. She is pouring water from ahst-jar in her right hand up on an offering table. This contains a lotus flower between two hist- jars (pl.52). 


\section{المغزى المدلولي الديني لسعف النخيل فى مقابر مصر خلال العصر اليوناني الروماني}

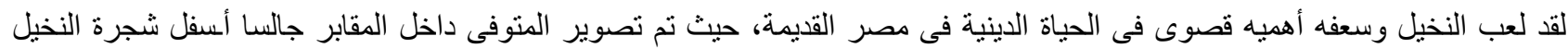

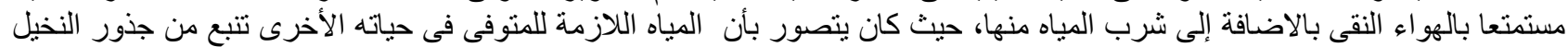

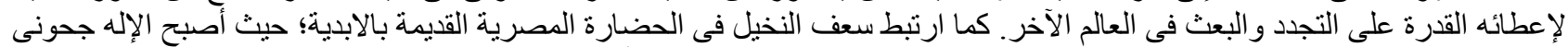

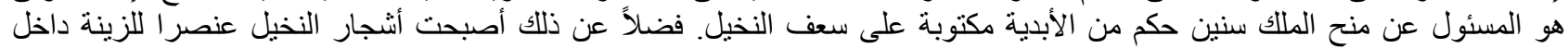

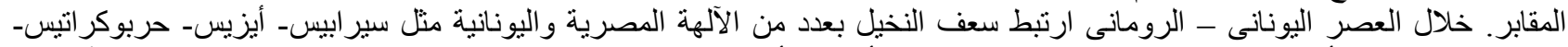

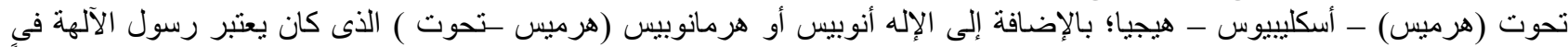

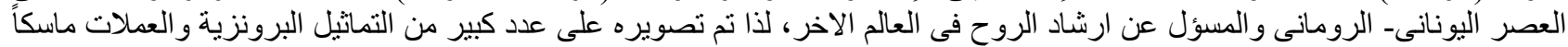

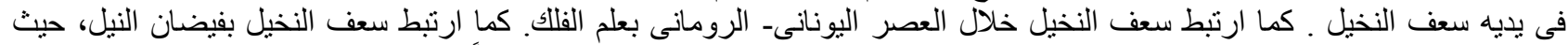

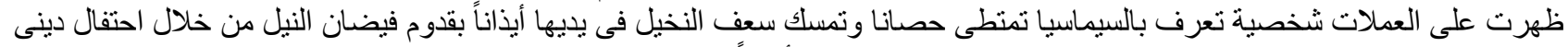

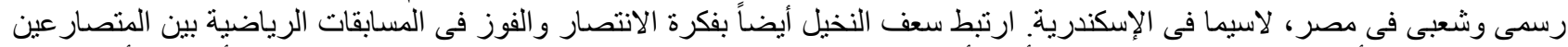

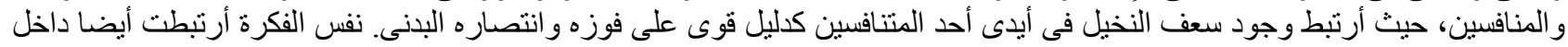

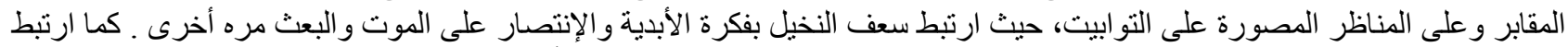

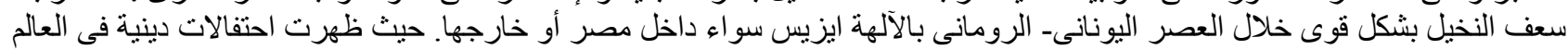

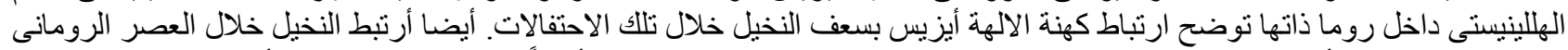

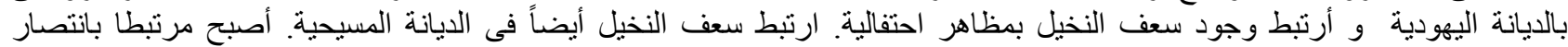

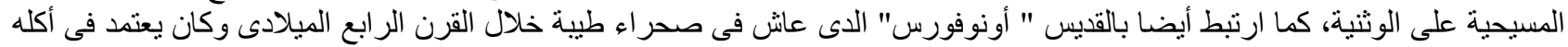

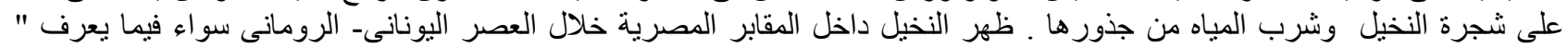

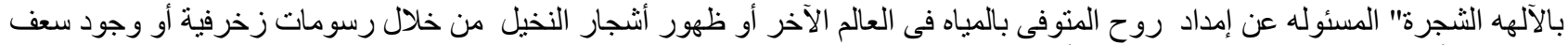
النخيل فى أيادى المنوفى دليل على بعثه مرة أخرى فى العى العالم الاخر.

الكلمات الدالة: سعف النخيل، العصر البوناني الروماني، التجدد والبعث، الإله جحوتي، التماثيل البرونزية 


\section{Plates}

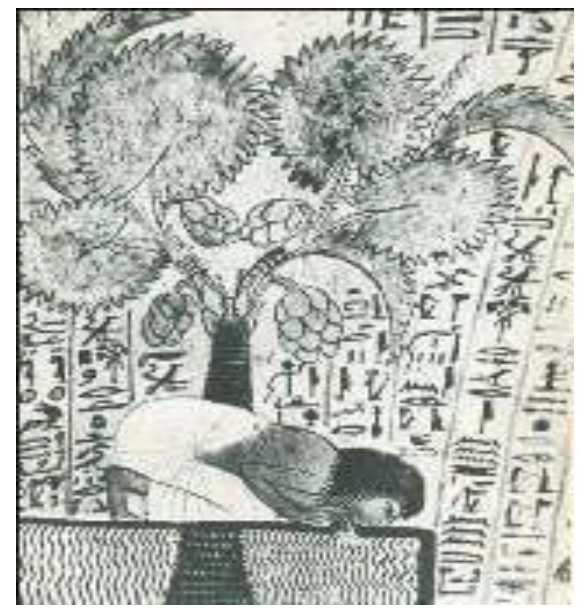

Pl.1The Dom palm of Min, Tomb of jri-nfr a Thebes

Wallert, I., Die Plamen, pl. XI

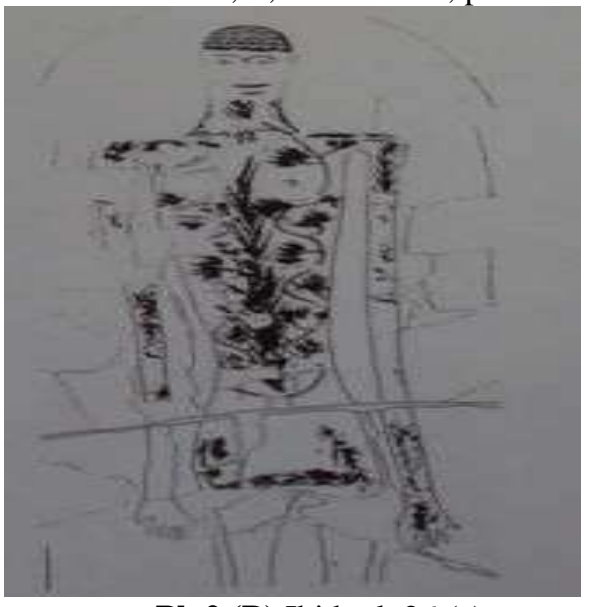

Pl. 2 (B).Ibid, pl. 26 (c)

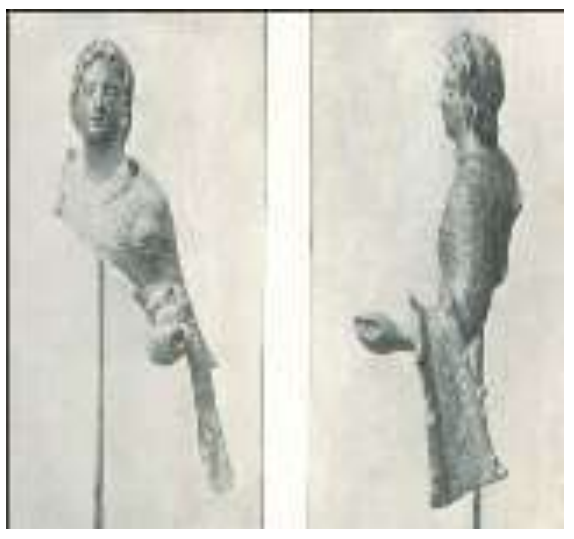

Pl.4 Alexander. Schreiber Th.,

Studien über das Bildniss Alexanders des Grossen, fig.XII

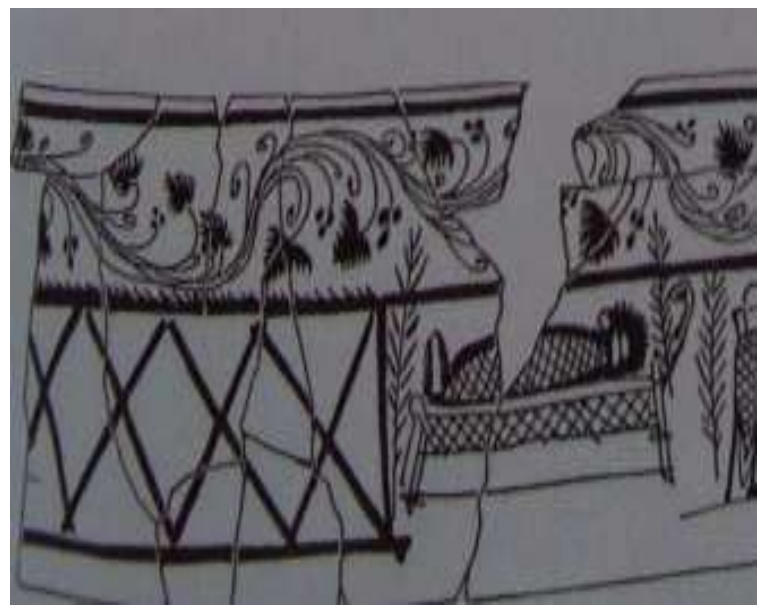

Pl.2 (A). A Coffin from Thebes Kaplan, I., Op. Cit, pl. 26(b)

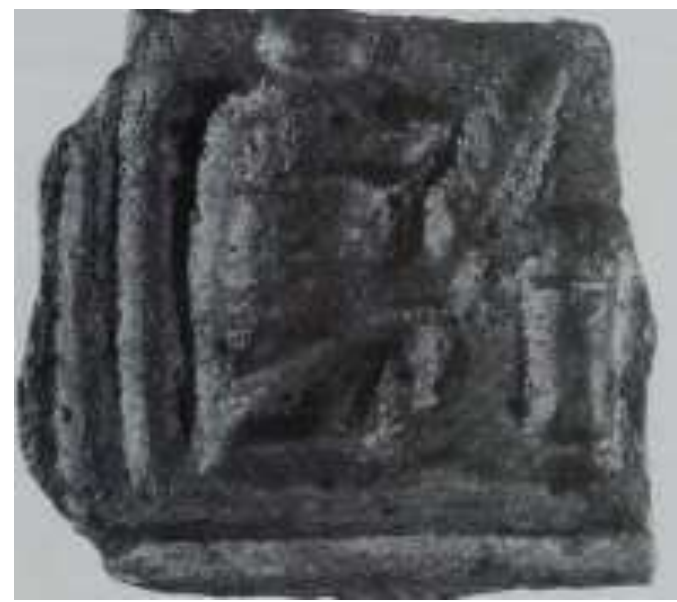

Pl.3Thot with the palm

Dunand, F., La Babouin Thot et la Palme, CdE(66),p.431, fig.1

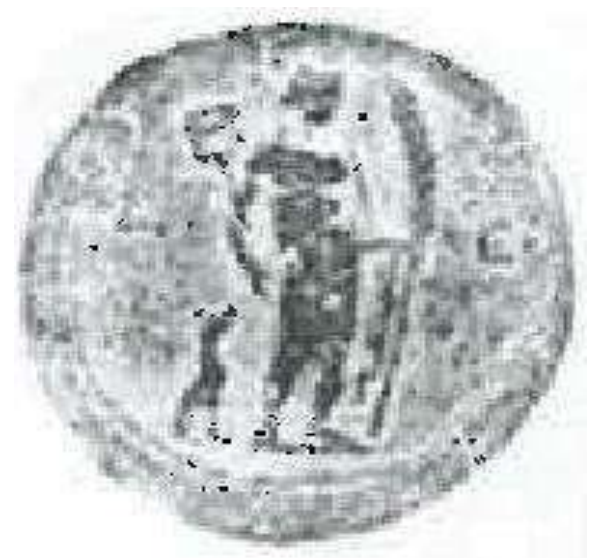

Pl.5Weber, $\mathrm{M}$ and Geissen, A., Die Alexandrinischen Gaumünzen, fig. 35 


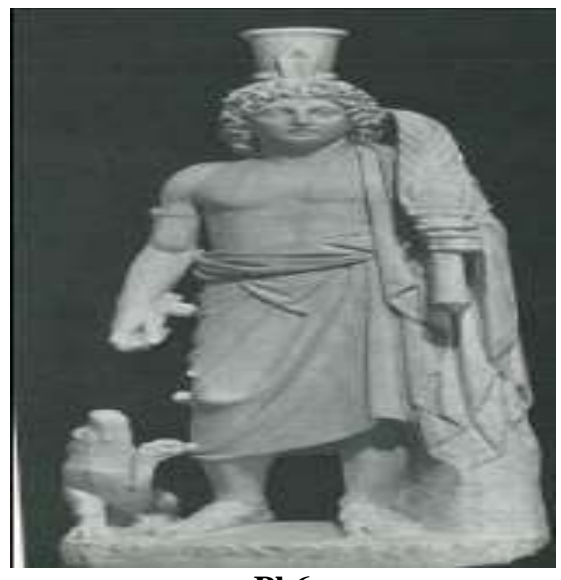

Pl.6

Adriani, A., Anuuaire (1935-1939), pl.LV

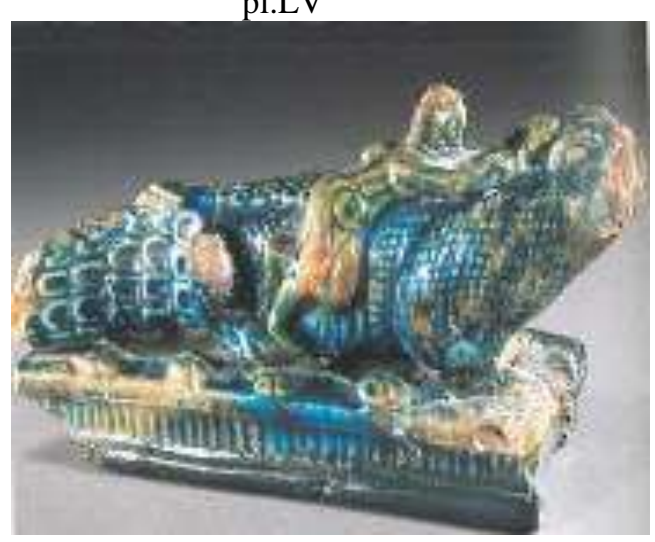

Pl.8 a Willems, H and Clarysse, W., Les Empereurs du Nil, à la mémoire de Jan

Quaegebeur, Leuven, 2000, pp.282-283, cat. 217

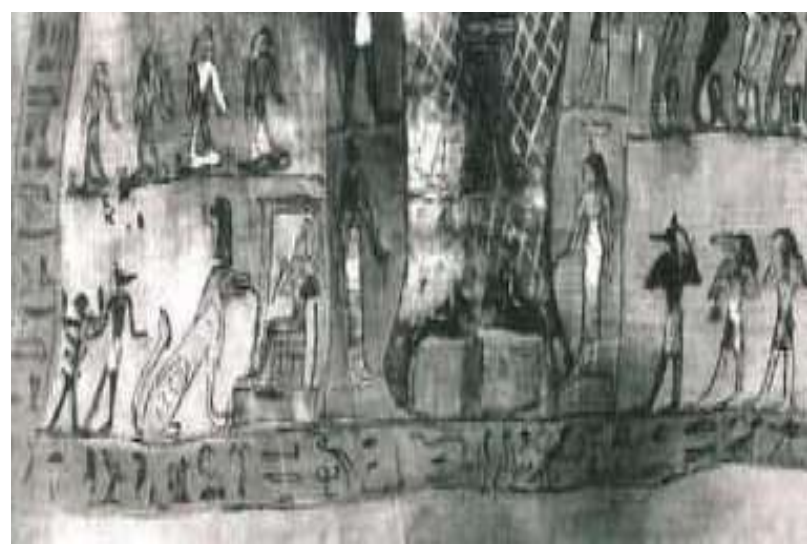

Pl.7 Materialien zum Toten glauben im römerzeitlichen Ägypten, Hützel, 2010, p. 80 , Fig. 5

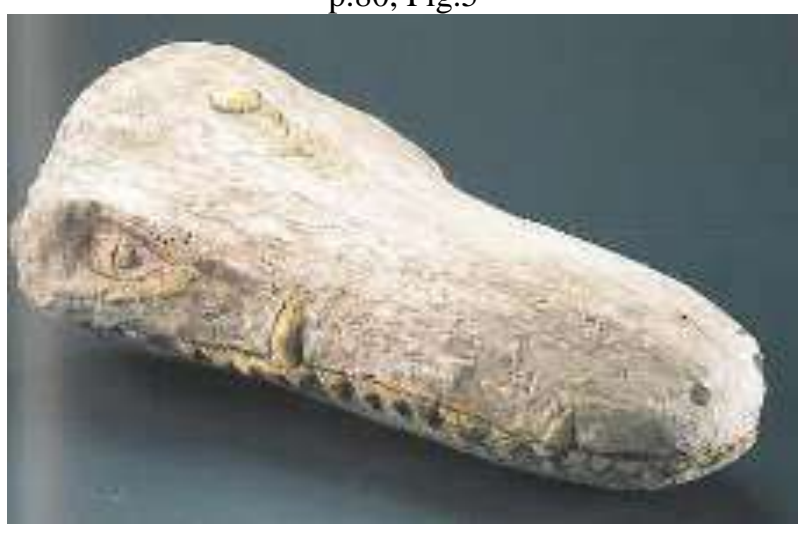

Pl.8 b

Ibid, cat. 21

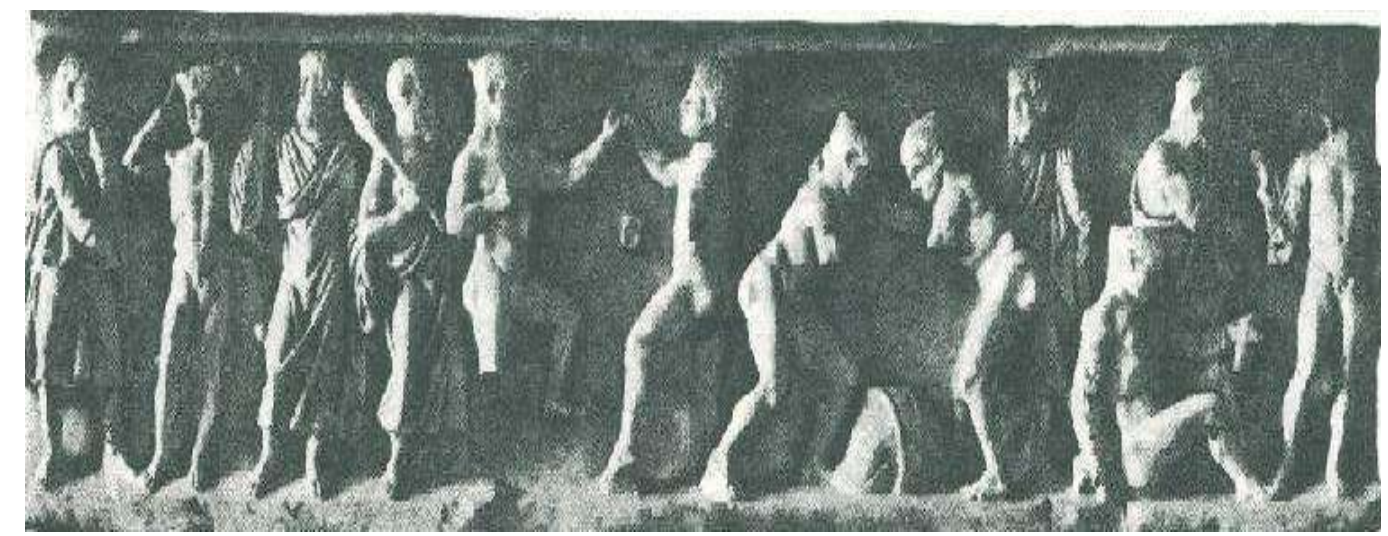

Pl.9 Curmont, F., "Recherches sur le Symbolisme Funeraire des Romains" in: BAH (25), Paris, 1942, p.464, fig. 100 


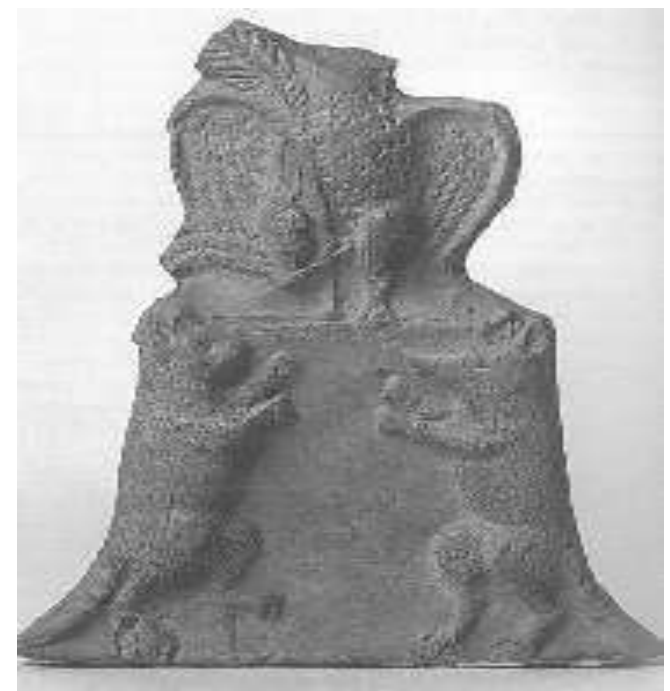

Pl.10

Fazzini, A. and Robert, B., Cleopatra's Egypt: age of the Ptolemies, New York, 1988, Cat.135.

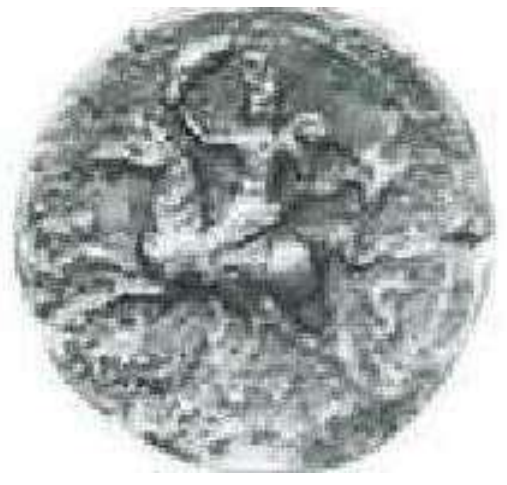

Pl.12The Semasia Meyboom, P., EPRO (121), pl.94
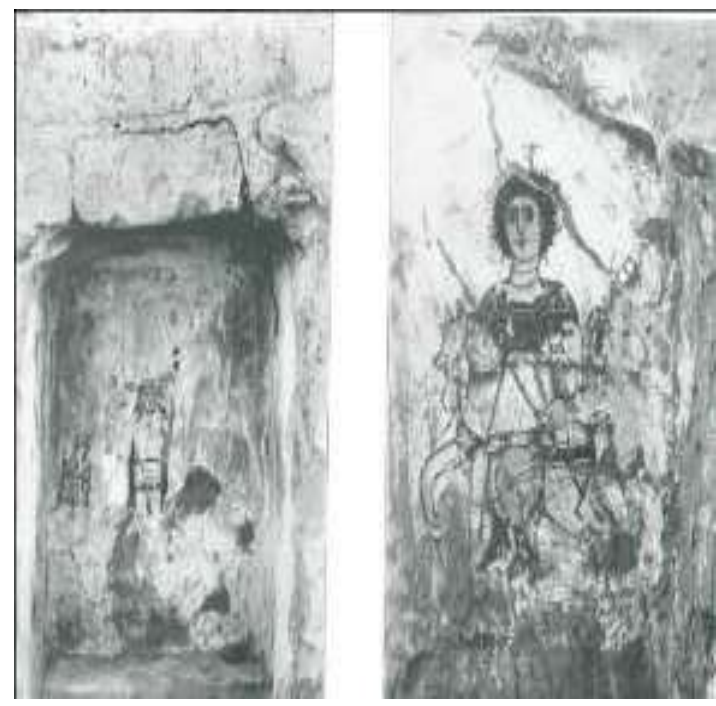

\section{Pl.11}

Boak, A and Peterson, E., Karanis, p. 34, pl. XXIV

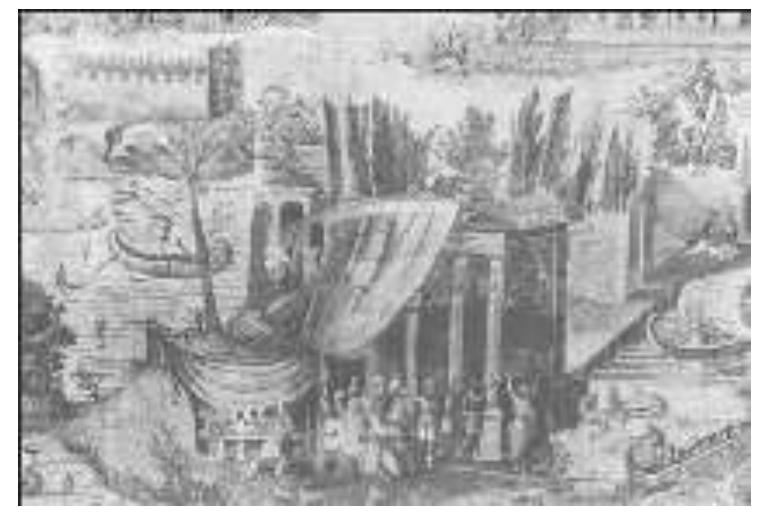

Pl.13

Ibid, pl.22

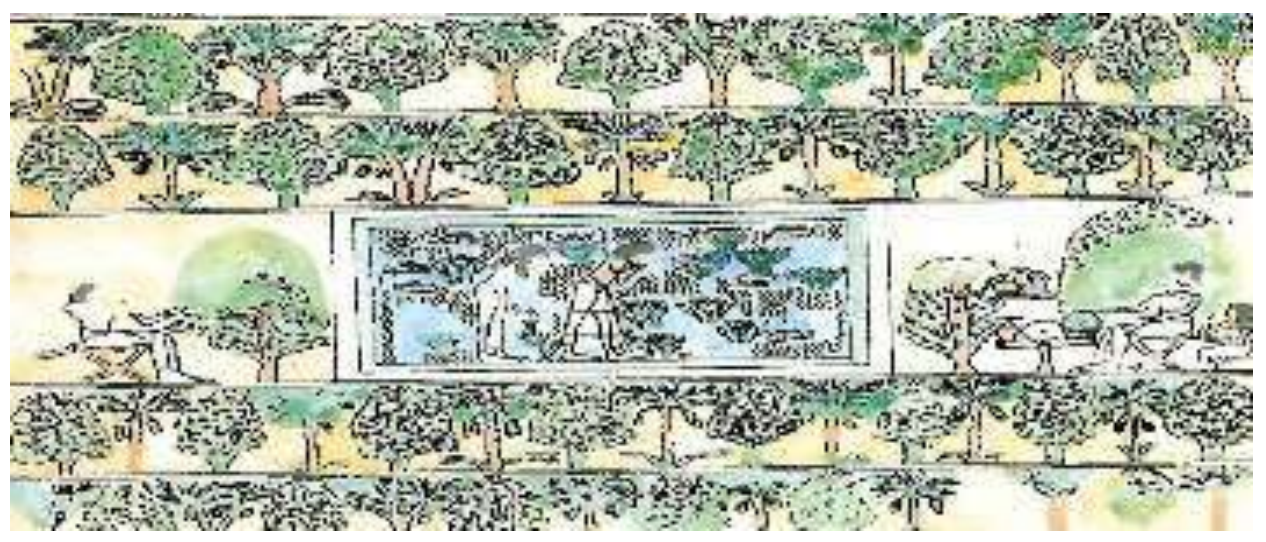

Pl.14Tomb TT 63.

El-Saddik, W., “Gartendarstellungen in Gräbern“, in: Ägyptische Gärten,p.94. 


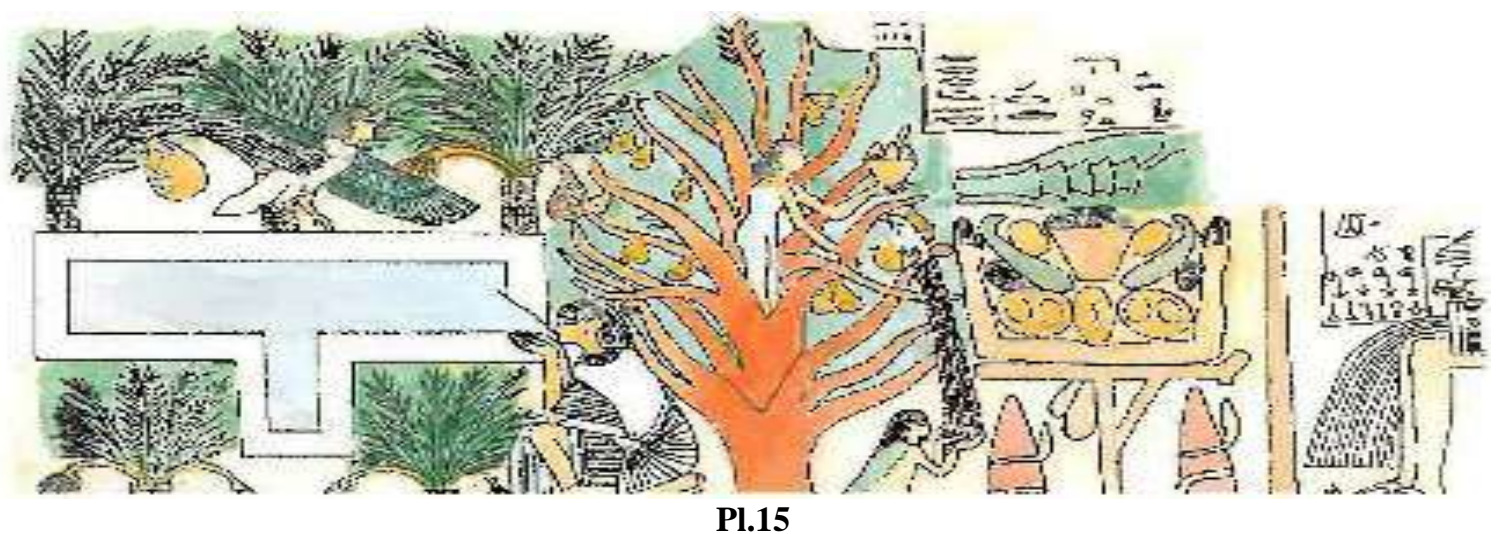

Tomb of Amun. TT.158, Ibid, p. p.95.

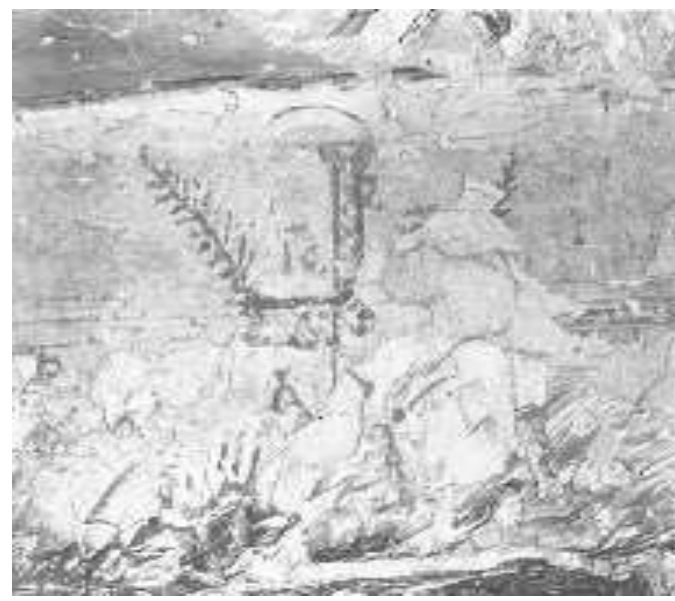

Pl.16 Cross with a palm branch.Tomb of Nebettaouy, nr. 60; Nelson, $\mathrm{M}$ and Janot, F., BIFAO (93), fig.10

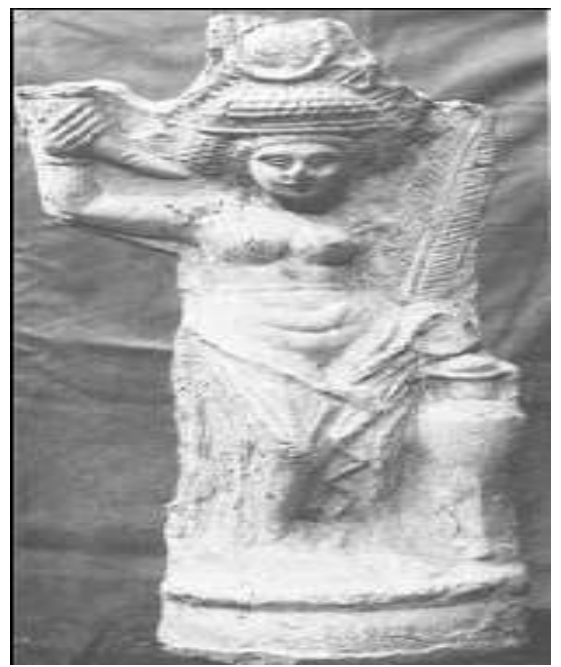

Pl.18

Dunand, F., EPRO (76), Pl. XXXII, 51

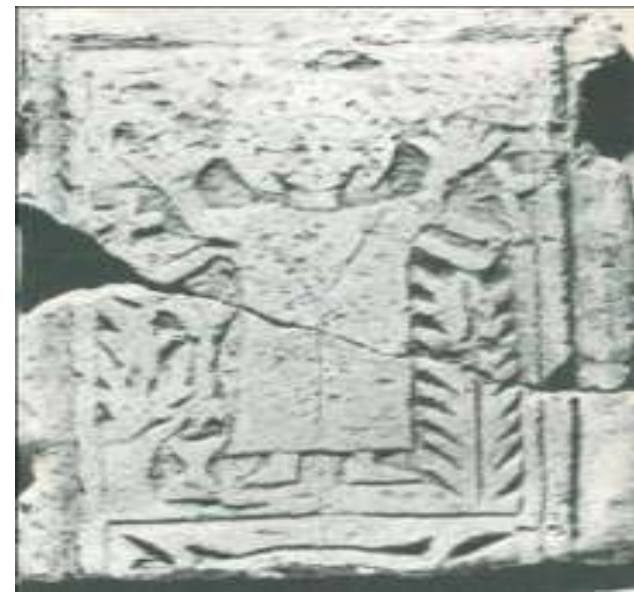

Pl.17a Coptic stele from Edfu? Of a worshipper between two palm branches in the Egyptian Museum of München, nr.147.

Gamer, W., Die Palmen, pl. VII

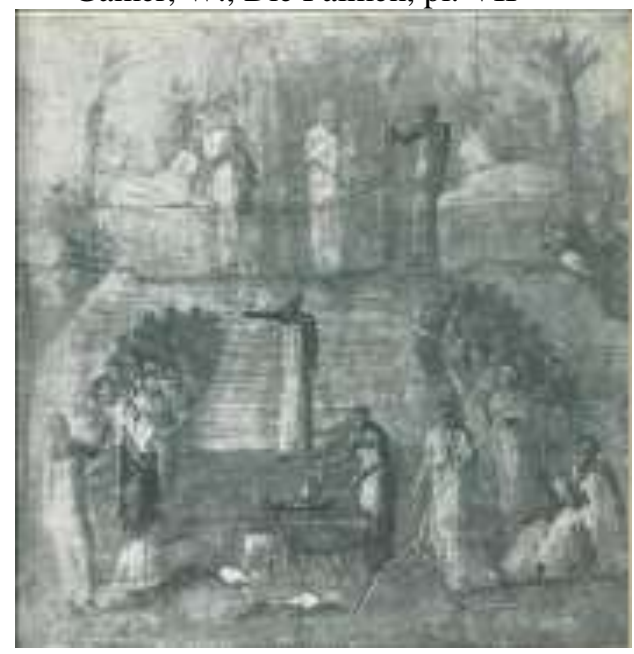

Pl.19

Wall- Painting of an Isiac ceremony- Tran Tam Tinth, V., EPRO (17), pl. XXVII, fig.40 


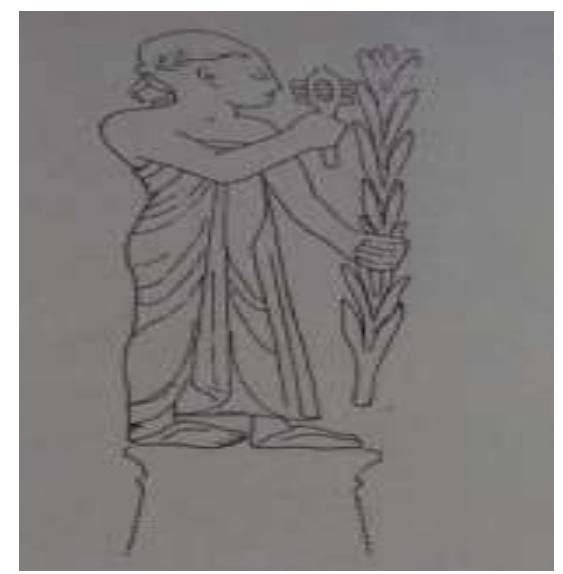

Pl.20 Column D- IseumCampense, Kaplan, I., Op. Cit, pl. 26 (a)

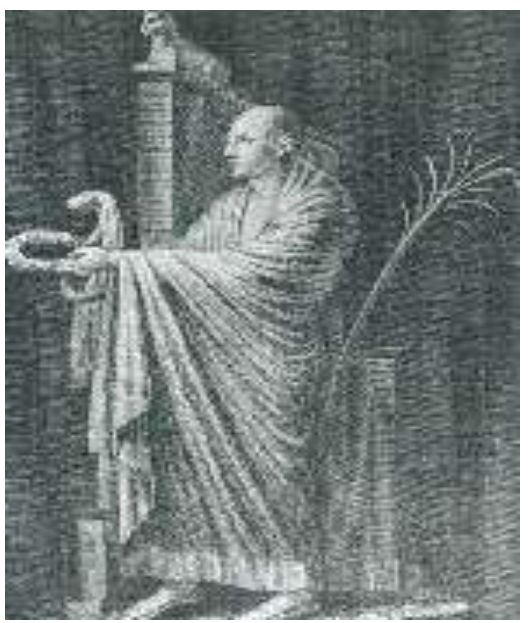

Pl.22Merkelbach, R., Isis regina, p. 597, fig. 12

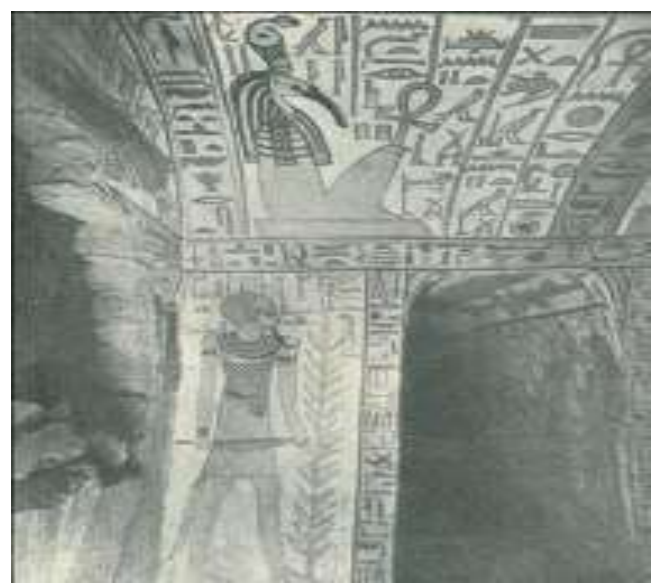

PI.25Deir el-Medina

Bruyer, B., BIFAO (3), p.153, fig.102

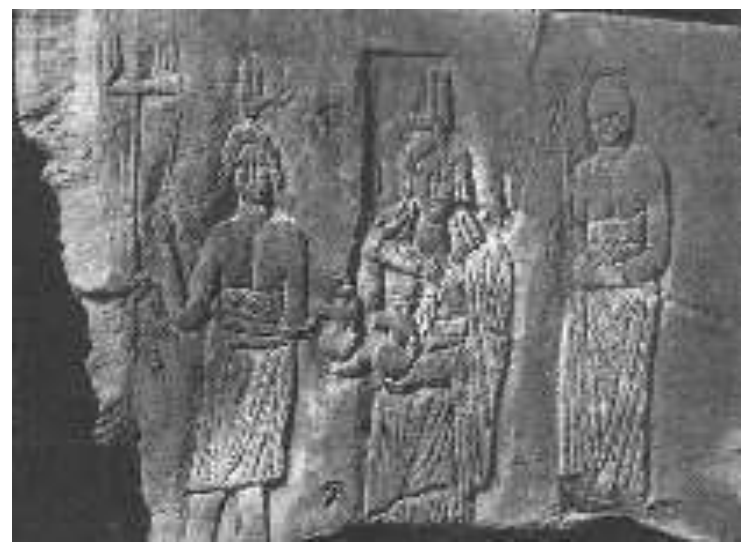

Pl.21Fazzini, A. and Robert, B., Cleopatra's Egypt: age of the Ptolemies, New York, 1988, Cat.129

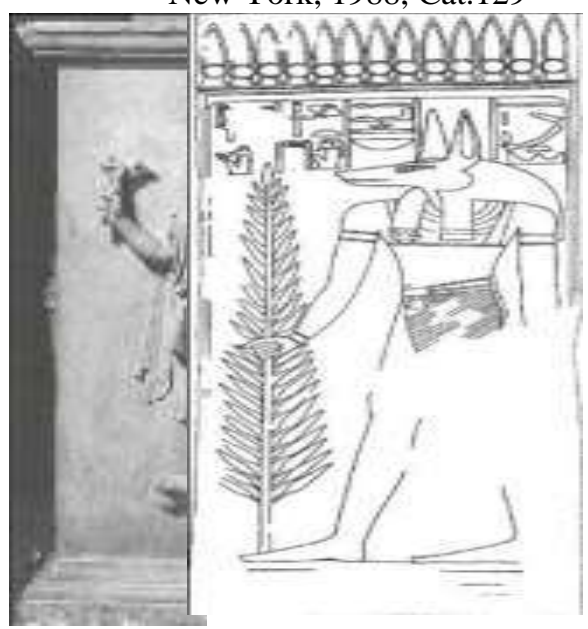

'I.23Grenier, Pl.24Anubis with the Palm, Valley J., EPRO of the queens, tomb. Nr. 40; Nelson, (57), $\quad$ M and Janot, F., BIFAO (93), fig.10 pl.XVIII, b

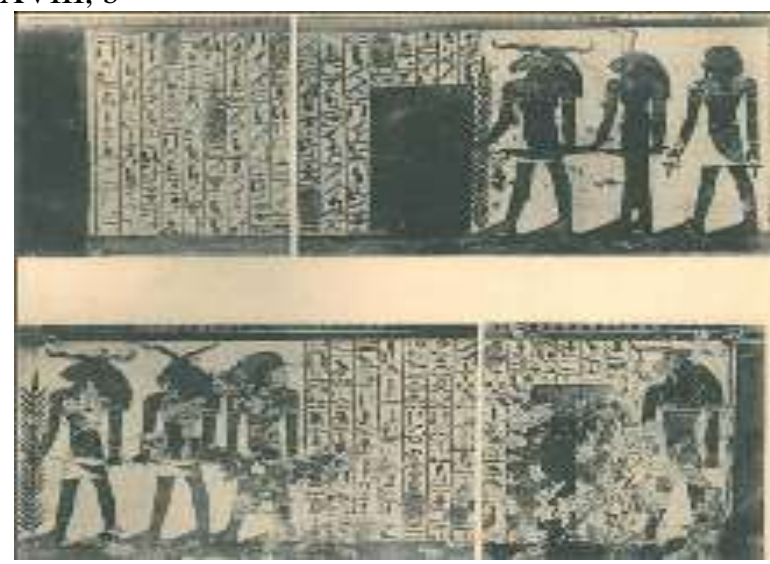

Pl.26Tomb of Nefertari Schiaparelli, E., Pl.XXIX. 


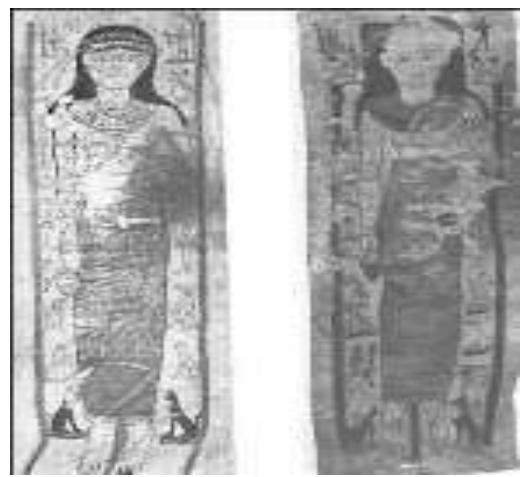

Pl.27Parlasca, K., Mumienportraits und verwandte Denkmäler, Wiesbaden,1966, pl.60

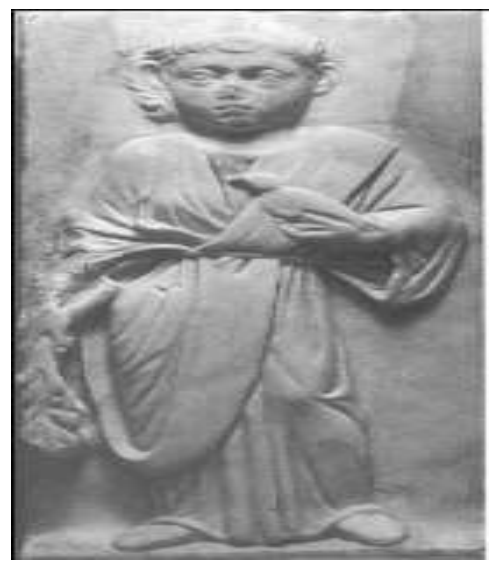

Pl.30

Merkelbach, R., Isis Regina, p. 597, fig. 125

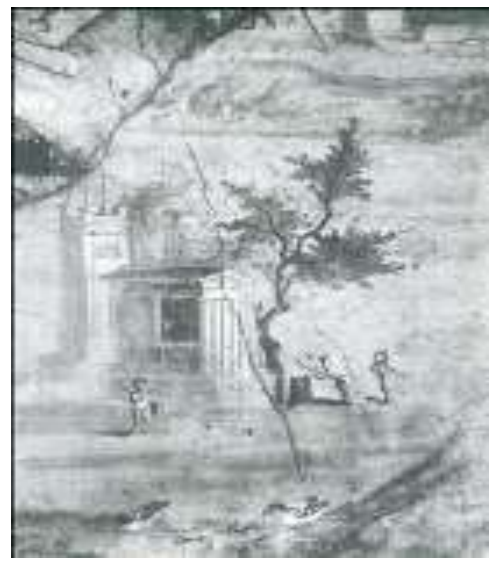

Pl.32

Meyboom, P., EPRO (121), pl.34

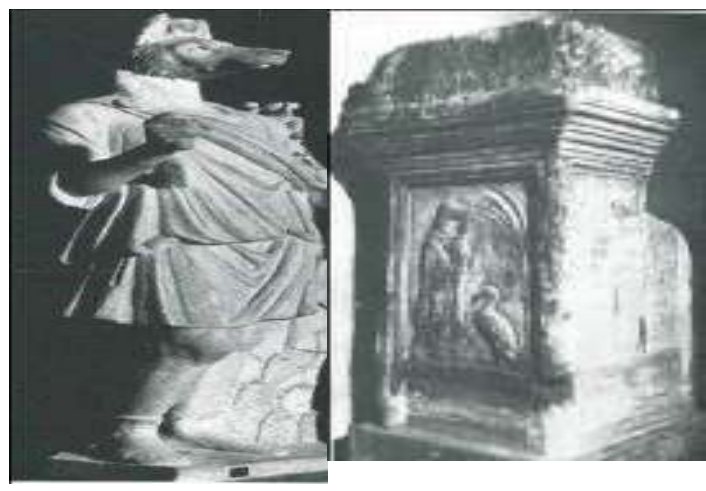

Pl.28. Anubis

Pl.29Grenier, pl. XIX

beside a palm

pillar; Gernier, J.,

Anubis Alexandrin

et Romain, pl. XVI

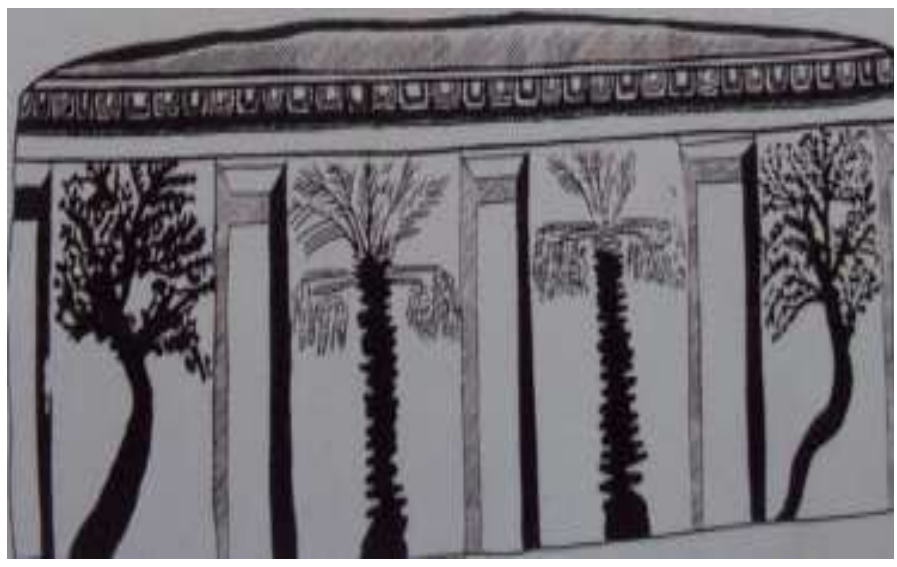

Pl.31Anfushy V.2-

Venit, M., Monumental Alexandria, fig. 72

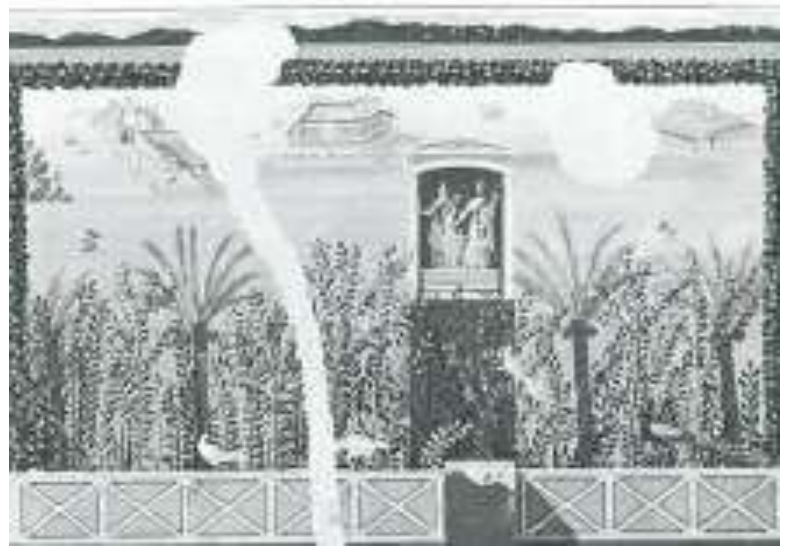

Pl.33 Fresco at Casa delleAmazzoni

at Pompeiirepresents an inundation scene; where Isis, Serapis and

Harpocrates in a shrine, Ibid, pl.92 


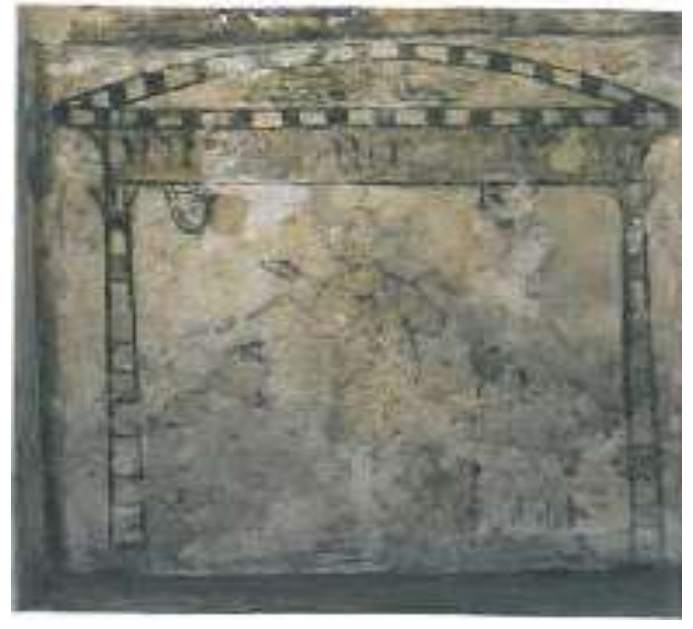

Pl.34Kaplan. I., pl. 66,a

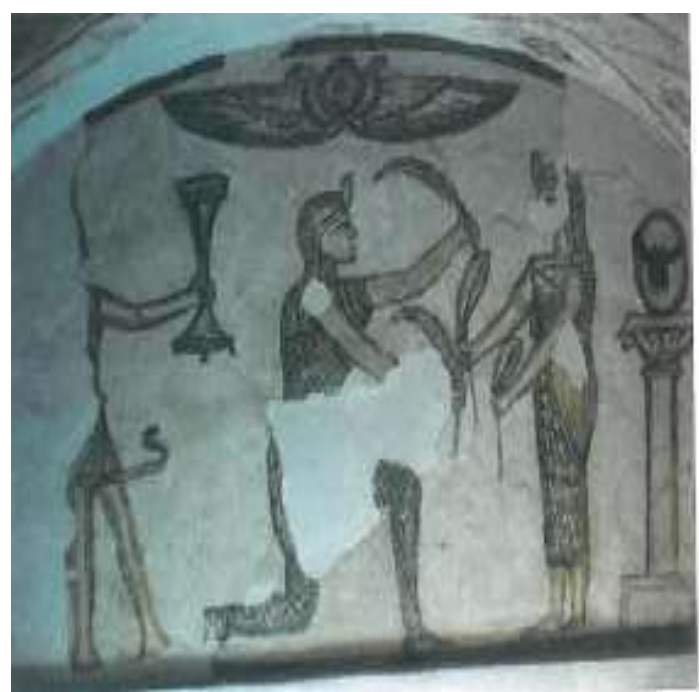

Pl.36 Ibid, pl.56, a

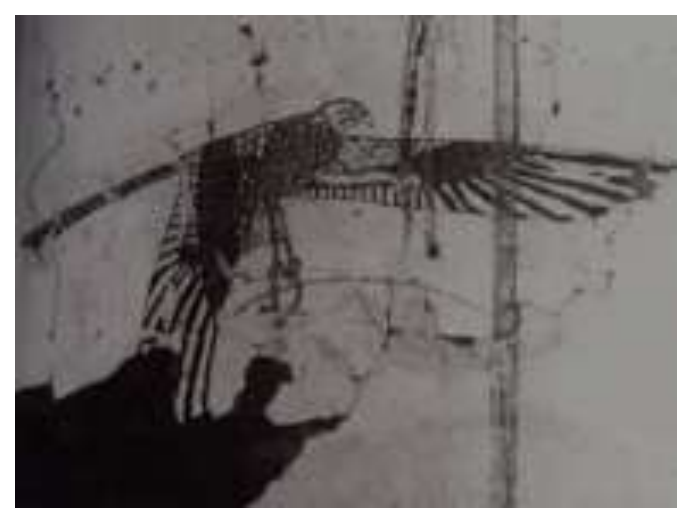

Pl.38House nr. 20 Gabra, S et al., pl. XLVIII, Kaplan, I., Op. Cit, pl.78 a

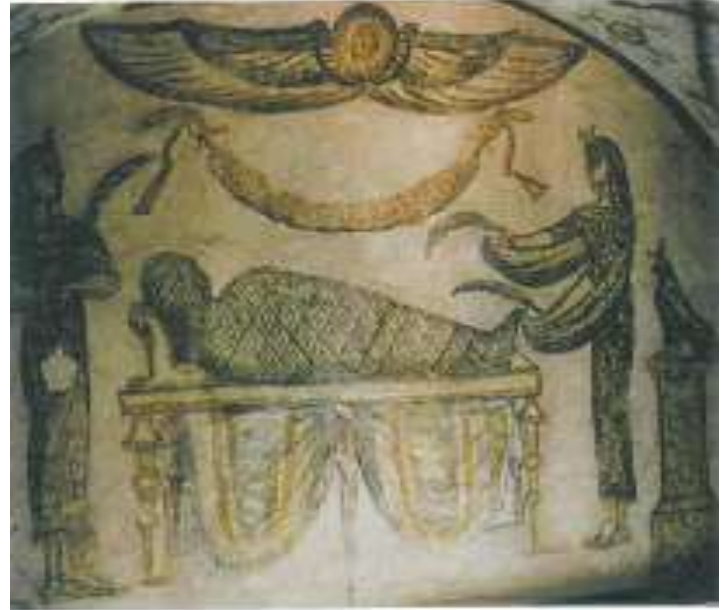

Pl.35Ibid, pl.54, a

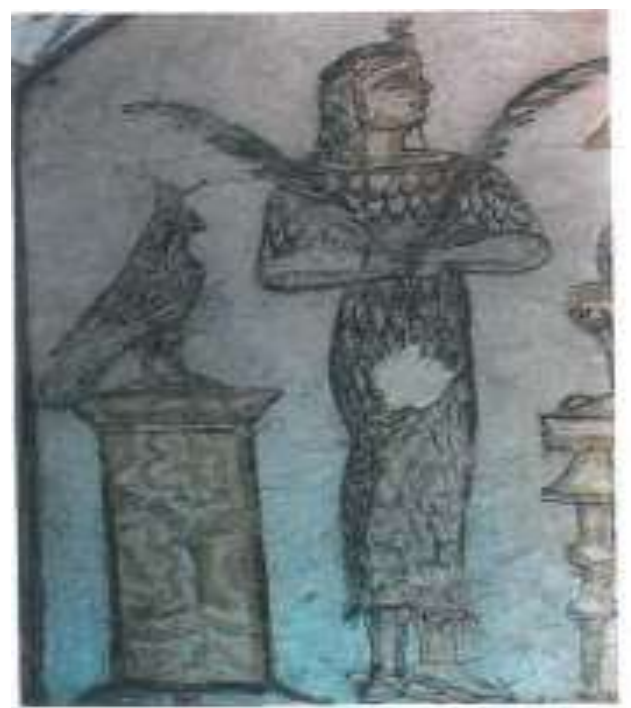

Pl.37Ibid, pl.54, b

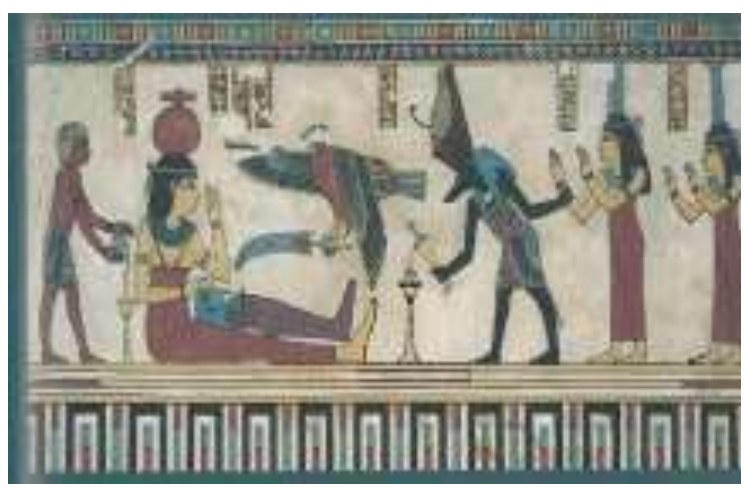

Pl. 39House nr. 21- Tuna el-Gebel Lembke,K et a., Ägypten späte Blüte, Die Romer am Nil, pl. XVI.2 


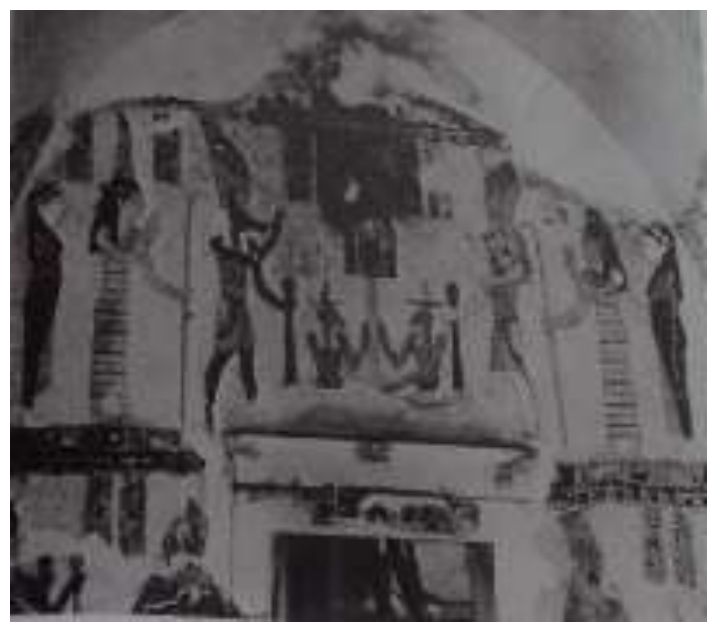

Pl.40House Nr.21

Gabra, S et al., Op. Cit, pl. XII

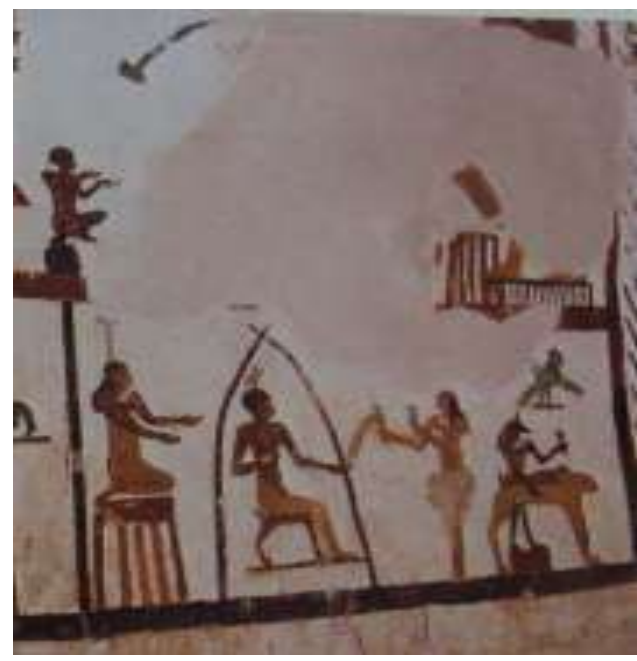

Pl.42Petubastis's Tomb - the northern wall; Ibid, pl. 31.d

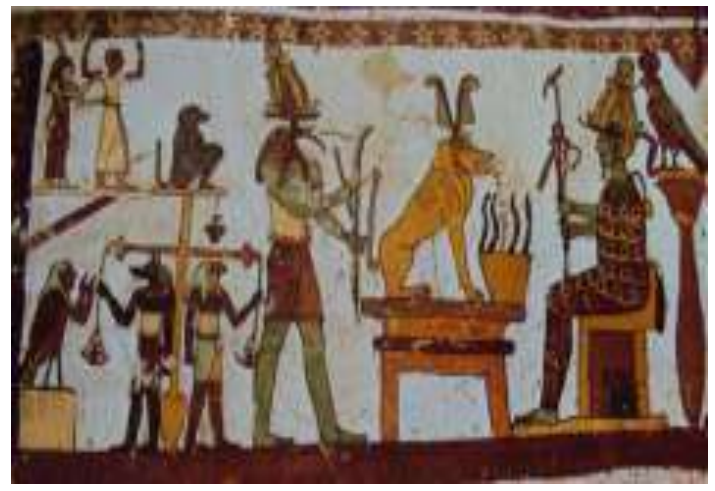

Pl.44Petosiris Tomb- Dachla.Osing, J., Denkmäler, pl.33 (a)

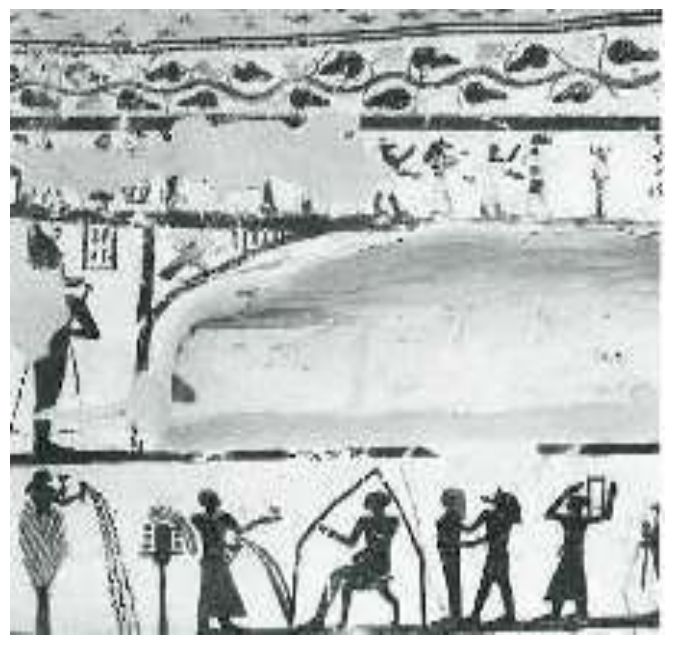

Pl.41Petubastis Tomb- the eastern wall Osing, J., Op. Cit, pl.22, a

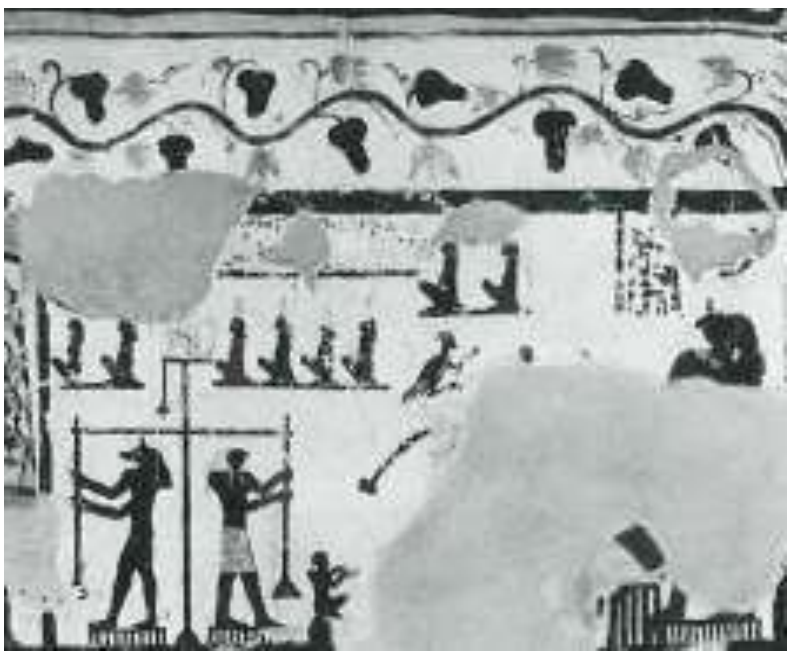

Pl.43 a Petubastis Tomb- the upper register of northern wall, Ibid, pl.24, c

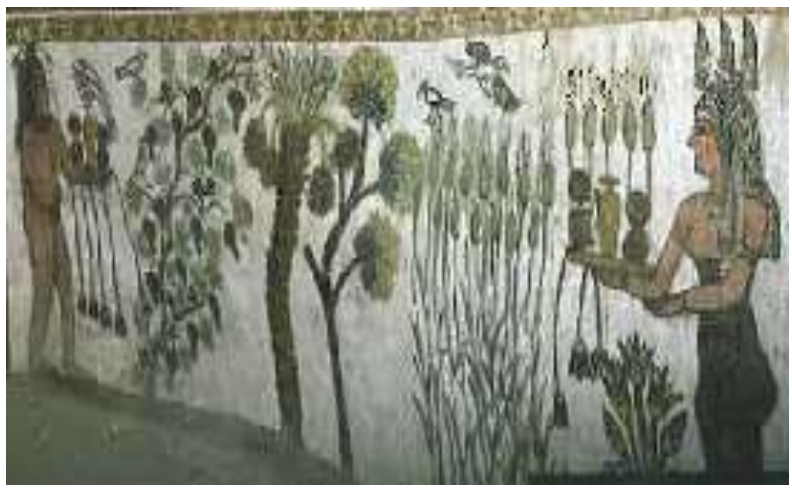

Pl.45Petosiris Tomb.Lembke, K etal., pl. 128 


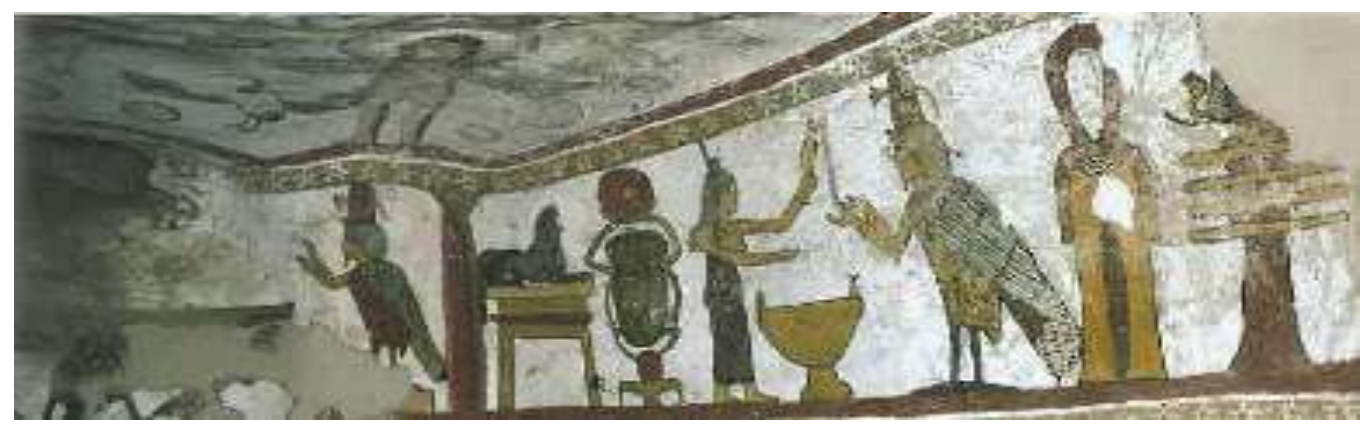

Pl.46, Lembke, K etal., p.70, pl.128
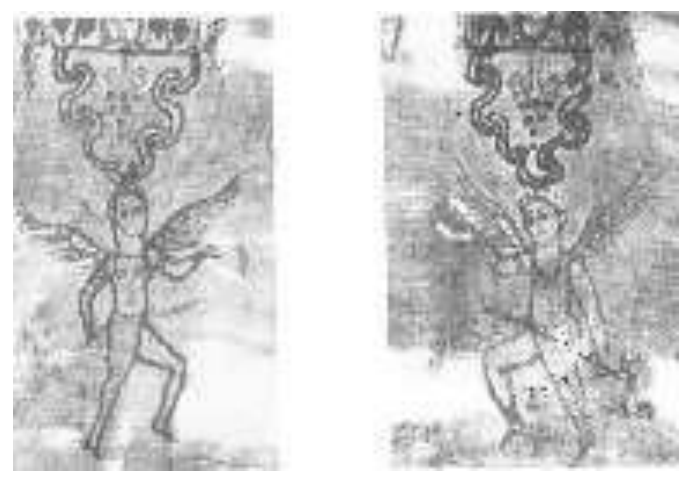

Pl.47 - Douch; Dunand, F et al., Douch, I, pl.59, 1

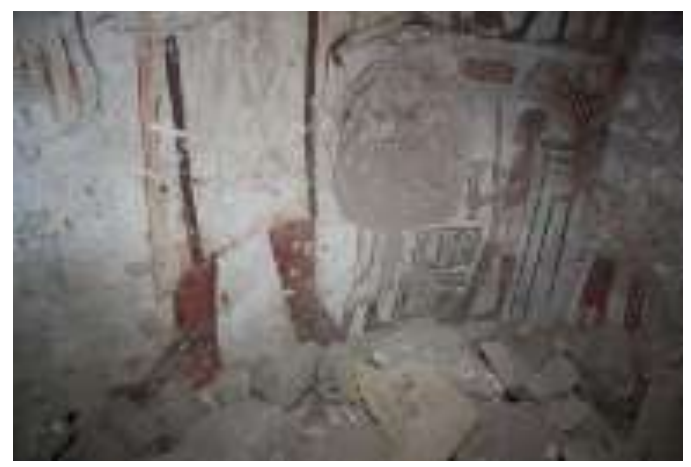

Pl.49 Tomb of von Bissing 1897-Akhmim Researcher's photo

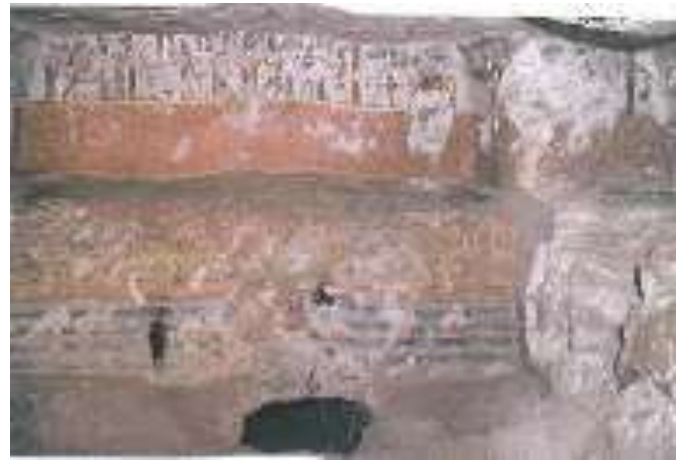

Pl.51Tomb VI-the niche

Kaplan, I., Op. Cit, pl.93, a

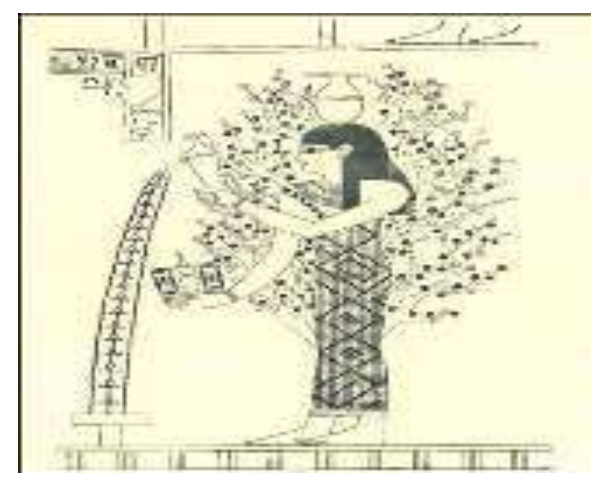

Pl.48 Tomb of Si-Amon

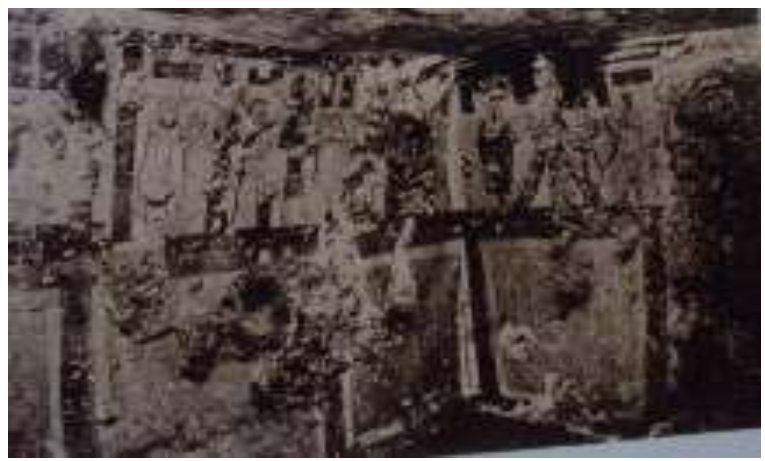

Pl.50Tomb IV- Akhmim

Kaplan, I., Op. Cit, pl. 92 (b)

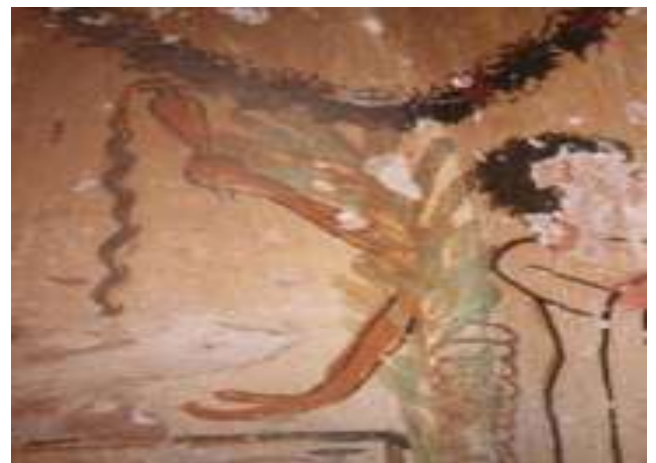

Pl.52The northern wall- Tomb IV Researcher's photo 


\section{Endnotes:}

1. Wallert, I., Die Palmen, MÄS (1),Berlin, 1962, pl. XI

: J思: 29663

. Buhl, M., "The Goddess of The Egyptian Tree Cult", in :JNES(6),1947, p.86

4. Baum, N., Arbres et Arbustes de l'Egypte Ancienne, Leuven, 1988, p. 118; Wallert, I., Op. Cit, pp.109-110

5. Quirke, S., Going out in Daylight, Prt m hrw, the Ancient Egyptian Book of the Dead, Translation, Sources, Meaning, London, 2013, p.145

6. The first appearance of the Dom- palm is appeared in the temple of Thot at Tuna el-Gebel. See Gabra, S., Fouilles de l'Universite "Fouad el Awal" a Touna el Gebel (HermopolisOuest)", in: ASAE (39), 1939, p.488

7. Wallert, I., Op. Cit, pp.101-103; Dils, P., "Stucco heads of crocodiles: a new aspect of crocodile mummification", in: Aegyptus (70), 1990, p.82

8. Kaplan, I., Grabmalerei und Grabreliefs der Römerzeit, Wechselwirkung zwischen der Ägyptischen und GriechischAlexandrinischen Kunst, Band (16), Vienna ,1999, p.119, pls. 26 b, c

9. Kaplan, I., Op. Cit, p.118

10. Wallert, I., Op. Cit, pp.105-108

11. Von Flack, M and Waitkus, W., "Heilige Bäume“, in: Ägyptische Gärten, (ed.by Tietze, C), Weimer, 2011, p.74

12. Wallert, I., Op. Cit, pp. 97-113

13. Von Flack, M and Waitkus, W., Op.Cit, p.72

14. Germer, P., " Flora", in: the Oxford Encyclopedia of Ancient Egypt (1), Oxford, 2001, p. 539

15. Ransom- Williams, C., Gold and Silver Jewelry and related Objects, New York, 1924, p.69, n.100

16. About the symbol of palm ribs in the temples see: Kaper, O., Temples and Gods in Roman Dakhlah, Studies in The Indigenous Cults of Egyptian Oasis, 1997, pp. 174-176

17. Erman, A., Aus dem Grabe eines Hohepriesters von Memphis”, in: ZÄS (33), 1895

18. Pyr. 1485a

19. Refai, H., “ Überlegungen zur Baumgöttin”, in: BIFAO (100), 2000, p.383

${ }^{20}$. Billing, N., "Nut, The Goddess of Life in Text and Iconography”, Uppsala Studies in Egyptology (5), Uppsala,2002, p.224

21. Buhl, M., Op. Cit, pp.93-95

22. Fakhry, A., The Oasis of Egypt, Vol. (1), Siwa Oasis, The American University in Cairo Press,1973, p.194,fig.71, Dunand, F and Lichtenberg, R., Oasis Egyptiennes, Les Iles de Bienheureux, 2008, p.110

23. Zingarelli, A.,"Some Considerations about the Water Offered (Poured) by the Tree-Goddess at TT49 “, in: L'AcquaNell'AnticoEgitto, Vita, Rigenerazione, Incantesimo, Medicamento, Proceedings of the First International Conference For Youung Egyptologists, Italy, ChiancianoTerme, October 15-18, 2003, Roma, 2005

24. Refai, H., "Hathor als Gleichzeitig West-und Baumgöttin", in: Timelines Studies in Honour of Manfred Bietak, OLA(149), Vol (1), (ed.by Czerny, E et al), Louvain, 2006, pp.287-290, id., "Die Göttin des Westens in den Thebanischen Gräbern der Neun Reiches: Darstellung, Bedeutung und Funktion", in: ADAIK(12), 1996

25. Buhl, M., Op. Cit, p.86

26. Lesko, B.,The Great Goddess of Egypt, 1999, pp.170-171; Buhl, M., Op. Cit, p.96.Naphtali Baum suggested that Isis as a tree goddess open the door for many other goddesses to play this role as local attributes as Naunet, Nephtys, Amenet, Neith, Maat and Thoeris, see Baum, N., Op. Cit, pp. 61, 69; Rifai, H., Op. Cit, p. 385, not.30

27. Griffiths, J., Apuleius of Madauros, The Isis-Book (Metamorphoses, Book XI), EPRO (39), Leiden, 1975, pp. 201-202

28. Tran Tam Tinth, V and Jental, M., Corpus des LampesIsiaques du MuseeGreco-romaind'Alexandrie, Quebec, 1993 , p.57

29. Tran Tam Tinth, Serapis depout, p.4

30. Preisendanz, K., Papyri Graecae Magicae, II, Leipzig-Berlin, 1931, p.73

31. Koemoth, P., Osiris et les arbres. Contribution à l'étude des arbressacrés de l'Égypteancienne, Liège, Centre Informatiquede Philosophie et Lettres, Aeg.Leod (3),Liège, 1994, p.272

32. Dunand, F., “Le babouinThot et la Palme, A propos d'uneterrcuited'Egypte”, in: CdE (66), 1991, pp. 341-348, fig.1

${ }^{33}$. Junker, H and Winter, E., DasGeburtshaus des Temples der Isis in Phila, Vienna, 1965, pp.380-381; thisfunctionisalsodepicted on the temple of Karnak . see: Helck, W.,"RamessidischeInschriftenausKarnak,“, in: ZÄS (82), 1957, p.133

34. Fischer, J.,"Die Entwicklung der Götterfigur in der griechisch- römischen Koroplastic Ägyptens“, in: Ägypten Griechenland Rom, p. 349; Bakhoum, S., Dieux egyptiens a Alexandrie sous les Antonines, 1999, p. 155; Bayer-Niemeier, E., GriechischRömische Terrakotten, Liebieghaus-Museum Alter Plastik, Bildwerke der Sammlung Kaufmann, Band (1), Melsungen, 1988, p. 49-

35. Griffiths, G., The Isis Book, p.201

36. Schreiber, Th., Studien über das Bildniss Alexanders des Grossen, Leipzig, 1903, pp. 145-147, fig.XII

37. Weber, M and Geissen, A., Die Alexandrinischen Gaumünzen der römischen Kaiserzeit, Die ägyptischen Gaue und ihre Ortsgötter im Spiegel der numismatischen Quellen, SSR (11), Wiesbaden, 2013, p.159, fig. 35

38 . Apulee, XI,11; Griffiths, Apulelus, 198-199; Pietschmann, “Anubis”, in: PW, 1894, p.2649; Griffiths, J., Op. Cit, p. 202

39. Milne, J., Catalogue of Alexandrian Coins, Oxford, 1933, pl.3,nr.1206

40. Adriani, A., Annuaire du MuseeGreco-romain (1935-1939), Alexandria, 1940, pl.LV

41 . Otto, W., Priester und Tempel im Hellenistischen Ägypten, Band (1), Roma, 1971,p p. 89-90

${ }^{42}$. Griffiths, J., Op. Cit, p. 202 
43. Widman, L., "Isis und Sarapis", in: Die orientalischen Religionen im Römerrich, EPRO (93), (ed. By Vermaseren, M), Leiden, 1981, p.132

44 . Kurth, D., Materialien zum Toten glauben im römerzeitlichen Ägypten, Hützel, 2010, p.80, fig.5

45. Seeber, C.,"Der Verstorbene im"Stadium der widergeburt", in: Untersuchungen zur Darstellung des Totengerichts im Alten Ägypten, MÄS (35), Berlin, 1976, pp. 101-108, figs. 35-40

46. Bricault. L and Veymiers, R., "Isis in Corinth: the Numismatic Evidence. City, Image and Religion”, in: Nile into Tiber, pp.410411

${ }^{47}$. Quaegebeur, J., "Mummy- labels: An Orientation“, in: TextesGrecs, Demotiques et Bilingues, (ed. by Boswinkel, E and Pestman, P), Brill, 1978, p. 240

48 . Dils, P., Op. Cit, pp. 83-85; Willems, H and Clarysse, W., Les Empereurs du Nil, à la mémoire de Jan Quaegebeur, Leuven, 2000, pp.282-283, cats. $217-218$

49. Malaise, M., les conditions de pénétration et de diffusion des culteségyptiens en Italie, EPRO (22), Leiden, p.210,n.2

${ }^{50}$. Nelson, M and Janot, F., "Une "Gisante” Renaissant de sesCendres”, in: BIFAO ( 93), 1993, pp. 373-375, figs.5, 8b, 9b

51. Griffith, J., Apuleius of Madauros, The Isis-Book (Metamorphoses, Book XI), EPRO (39), Leiden, 1975, p.135

52 . Koemoth, P., Op. Cit, p. 272

53. Bernhardt, P., Op. Cit, pp. 183-184

54. Wallert, I., Op. Cit, p.103

55. Cumont, F., Recherches sur le symbolisme funéraire des Romains, Paris, 1942, pp. 469-470, 481-484

56. Ibid, Fig. 100

57 . Ibid, p. 470

58. Fazzini, A. and Robert, B., Cleopatra's Egypt: age of the Ptolemies, New York, 1988, pp.246-247 (cat. 135)

59. Cumont, F., Op. Citp. 481

${ }^{60}$. Rondot, V., Derniers Visages des Dieuxd'Egypte, Iconographies, Pantheons et Cultesdans le Fayoumhellénise des II-III Siècles de notre ère, Louvre, 2013, pp.141-145, 283-292; id., “Le Dieu a la Bippene, C'esLycurgue”, in RdE (52), 2001, pp.219-236, pl. XXIX; Tallet, G and Zivie-Coche, C., "Imported Cults", in : The Oxford Handbook of Roman Egypt, Oxford, 2012, p. 439, pp.444-44, fig. 26,2. Heron also appeared in dipinto inside the temple of Deir el-Hagar at Dachla Oasis, Kaper, O and Worp, K., "Dipint on the Temenos Wall at Deir el-Haggar (Dakhla Oasis)", in: BIFAO (99), 1999, p.248, fig.15

61. Tallet, G and Zivie-Coche, C., Op. Cit, p. 439

${ }^{62}$. It is No. 15979 in Berlin Museum, was excavated by Rubenson, O., "AusGriechisch- RömischenHäusern des Fayoum“, in: JDAI (20), 1905, p. 20; Kiss, Z., "Etudes sur le Portrait imperial romaine en Egypte", in: Travaux du centred'archeologieMediterranean de $1^{\prime}$ Academie polonaise des Sciences(23), 1984, pp. 83, 185, fig.214;

Rondot, V., “"Le Dieu a la Bippene, C'esLycurgue”, in RdE (52), p. 22

${ }^{64}$. Parlasca, K., "Bildnisse mit Nimbus in der Kaiserzeitlichen Kunst Ägyptens“, in: Archeologia (69), Rocznik Instytutu Archeologii i Etnologii Polskiej Akademii Nauks (1998), pp.7-10, pl. II,3

65. About the Semasiasee: Bonneau, D., La Crue du Nil, DivinitésEgyptienne, a travers mille ansd'histoire (332av-641 ap. J.-C), Paris, 1964, pp. 375-377. The level of 16 cubits of the Nile could be indicated by Nilometers by the semeion which could be the figure of Ankh, life, an appropriate sign for a new crop, or a piece of stone encrusted in the wall. Bonneau, D., Le Fiscet le Nil, Incidences des irrégularités de la crue du Nil sur la fiscalitefoncieredansl'Egyptegrecque et romaine, Paris, 1971, pp.36, 63, note.261. When the semeion mark reached the signal, was given to cut the disks which had blocked the irrigation canals to enable the inundation to spread in the whole country in a great celebration, in which the sovereigns participated, everyone had a holiday and all along the Nile, especially near the temples of Isis and Osiris, there were banquets and revels, eating and drinking, dancing and boating, the lotus which began to blossom by the arrival of the inundation, is the first sign of rebirth and vegetation. Meyboom, P., "Description", in: The Nile Mosaic of Palestine, Early Evidence of Egyptian Religion in Italy, EPRO (121), Leiden, 1995, pp. 72-73

66. Swetnam- Burland, M., "Nilotica and the Image of Egypt", in: the Oxford Handbook of Roman Egypt, pp. 684-685

67. Swetnam- Burland, M., "Egyptian Objects, Roman Contexts: A Taste for Aegyptiaca in Italy", in: Nile into Tiber, Egypt in the Roman World, Proceedings of the III ${ }^{\mathrm{rd}}$ International Conference of Isis Studies, Leiden, May 11-14 2005, (ed. by Bricault, L et al), Leiden, 2007, pp.113-136

${ }^{68}$. Vöros, G., The Ancient heritage of Taposiris Magna in Italy: Palestrina, Fiesole, Rome", in: : Faraoni Come deiTolemei come Faraoni, Atti del V CongressoInternazionaleItalo- Egiziano, (ed. by Bonacasa, N et al), Torino- Palermo 2003, p.287

69. Meyboor, P., The Nile Mosaic, pp. 56-60

70 . Ibid, pp. 64-69, figs.22, 94

71. Ibid., fig. 92

72. Ibid., p.329, note. 180

73 . Ibid., p. 263 , note. 145

74. Other garden - tombs with the palm trees such as the tomb of Ineni at Thebes (TT 81), and the fragments of the Tomb of Nebamun in the British Museum, tomb of Kenamun (TT 93), the vizier Rechmire (TT 100), and the tomb of Ipui (TT 217) see :El-Saddik, W., “ Gartendarstellungen in Gräbern“, in: ÄgyptischeGärten, pp. 90-100

75 . Wallert, I., Die Palmen, pl.V

76. Otto,W., Priester und Tempel in Hellenistischen Aegypten, Ein Beiträge zur Kulturgeschichte des Hellenismus,Band (II), Leipzig, 1971, p.12 
77. Roullet, A., The Egyptian and Egyptianizing Monuments of Imperial Rome, EPRO (20), Leiden, 1972, pl. XXV, no.38, pl.XXVIII, no.41; Wild, R., Water in the Cultic Worship of Isis and Sarapis, EPRO (87), Leiden, 1981, pl. XVIII

78. Dunand, F., Religion Populaire en Egypte Romaine, EPRO (76), Leiden, 1979, pl. XXXII, no.51

79. Bookidis, N and Strouds, R., the Sanctuary of Demeter and Kore. Topography and Architecture, Corinth, XVIII/3, The American School of Classical Studies at Athens, 1997, pp.369-370

${ }^{80}$. Deonna, W., “L'ex-voto de Cypselos a Delphes: le symbolisme du palmier et des grenouilles”, in: RHR (139), 1951, pp. 162-207

81. Le Corsu, F., Isis: Mythe et mystères, Paris, 1977, pp.142-144

82. Tran Tam Tinth, V., Le Cultes de DivinitésOrientales a Herculanum, EPRO (17), Leiden, 1971, pl.XXVII-XXVIII

83. Malaise, M., Inventaire Préliminaire des Documents Egyptiens découverts en Italie, EPRO (21), Leiden, 1972, pp. 58-59, pl.2

84. Witt, R., Op. Cit, pp.98, 167

85 . Bosticco, S., Musei Capitoline: I MonumentiEgizie d' Egitizzanti, Rome, 1952, pl.7; Kaplan, I., Op. Cit, p. 119 , pl. 26 a

86. Wild, R., Water in the Cultic Worship of Isis and Sarapis, EPRO (87), Leiden, 1981, p. 118, pl. XVIII,4

${ }^{87}$. The relief is in Römer und Pelizäus Museum, Pelizaus Museum at Hildesheim. Fazzini, R and Robert, B., Cleopatra's Egypt: age of the Ptolemies, New York: The Brooklyn Museum. Exhibition catalogue, director Richard A. Fazzini, exhibition curator Robert S. Bianchi, 1988, pp. 240-241, cat.129; Bommas, M., ., Heiligtümer ägyptischer Gottheiten und ihre Ausstattung in hellenistischer und römischer Zeit“, in: Ägypten, Griechen and Rom, Abwehr und Berührung, Munich, 2004, p. 635, kat.218

${ }^{88}$. Merkelbach, R., Isis regina - Zeus Sarapis: die griechisch-ägyptische Religion nach den Quellen dargestellt, $2^{\text {.nd }}$ revised ed. Leipzig; München, 2001, fig.11

89. Ibid, p.497, fig. 12

90 . Witt, R., Op. Cit, pp. 256-257

91 . Tran, V., Le Culte des DivinitésOrientales a Herculanum, EPRO (17), Leiden, 1971, pls. XXVII, fig.40, pl. XXVIII, fig.41

92. Grenier, J., Anubis alexandrin et romain, EPRO (57), Leiden, 1977, pp.71, 139

93. Malaise, M., Les Conditions de Penetration et de Diffusion des Culteségyptiens en Italie, EPRO (22), Leiden, 1972, p.210

${ }^{94}$. Dunand, F., La BabouinThot, p.345, notes. 20,21; Grenier, J., L'autelfuneraireisiaque de FabiaStratonice, Leyde, 1978, pp.6-7, pls. IV-V;

95. Grenier, G, Anubis Alexandrien, pl. XVIII(b). Adriani, A., Annuaire du Musée Greco-romian, 1935-39, 1940, pl. LV.1; id., Hermanuoubis has a great cult center at Alexandria, at Ras el-Soda, SB, I, 3482. The function of Anubis as "Psychopompus" leading the deceased in the underworld appeared on the mummy cases anointing the deceased on painted linen shrouds and mummy labels see. Parlasca, K., Mumienporträts und verwandteDenjmäler, Wiesbaden, 1966, pls. 12.1, 35.1. The earliest evidence of the sacred meal in the Graeco- Roman period dates back to the Ptolemaic period refers to a banquet at Tebtunis, P.Tebt. I,18, the funerary meals of the Roman period were celebrated during the birthday of the deceased Hopkins, Death and Renewal, Cambridge, 1975, pp.226-234, some of these funerary meals were dedicated for god Serapis as " the kline of Serapis", there are 15 funerary meals dedicated for Serapis were known , Montserrat, D., The Kline of Anubis", in: JEA(78), 1998, p. 304

96. Parlasca, K., "Anubis mitdemSchlüssel in der KaiserzeitlichenGrabkunstÄgypten", in: Isis on the Nile, Egyptian Gods in Hellenistic and Roman Egypt, Proceedings of the $\mathrm{IV}^{\text {th }}$ International Conference of Isis Studies, Liege, November 27-29 2008, (ed. By. Bricault, L and Versluys, M), EPRO (171), Leiden, 2010, pp. 221-232

97. Leblanc, C., Ta Set Neferou.Unenecropole de Thebes-ouest et son histoire, I, Le Caire, 1989, pl. LXXVI; Nelson, M and Janot, F., "Une " Gisante" Renaissant de sesCendres", p.376, fig.10

98. Bruyer, B., "Fouilles de Deir el Medineh (1924-1925), ResultatsArcheologiques", in: FIFAO (3), Le Caire, 1926, p. 153, fig.102

99. Schiaparelli, E., Relazionesur la voridellaMissioneArcheologicaItaliana in Egitto (Anni 1903-1920), Vol. (1), Turin, 1924, pl. XXIX

${ }^{100}$.Piankoff, A., The tomb of RamessesVI,Text. Vol. (ed.by Rambova, N), Egyptian Religious Texts and Representations 1; Bollingen Series 40 (1), New York, 1954,p.298, figs. 75, 83 ; Bruyer, B., Op. Cit, pp.153, 166; Griffiths, J., The Isis-Bok, p. 203

${ }^{101}$. Nelson, M and Janot, F., Op. Cit, p. 375

${ }^{102}$. Ibid, p.377; Leblanc, C., "Les Tombes N 58 (Anonyme) et $\mathrm{N}^{\mathrm{o}} 60$ (Nebet-Taouy) de la Vallée des Reines (Rapport Préliminaire)", in: ASAE (69), 1983, p.34, pl.II.C

103 . Wessetzky, V., Die Ägyptische Kulte zur Römerzeit in Ungarn, EPRO (1), Leiden, 1961, pl.II, fig.4

${ }^{104}$. Drexler, W., Der Cults der aegyptische Gottheiten in den Donauländern, Leipzig, 1890, p.43

105 . Ibid, p.106

106 . Parlasca, K., Mumienportraits und verwandte Denkmäler, pl.60; Koemoth, P., Osiris et les arbres, pp.263-264, figs. 30, 31

${ }_{107}$. Grenier, J., Anubis Alexandrian, nos. 213-214, pls.XVI-XVII

108 . Ibid, no.227, pl. XIX

109. Merkelbach, R., Isis regina, p. 614, fig. 144. The stela is now in Capitoline Museum

$110^{\circ}$ Ibid, p.601, fig. 130; Grenier, J., L'autelfuneraireisiaque de FabiaStratonica, EPRO (71), Leiden, 1978, pp. 15-18, pls. IV, V;

111 . Witt, R., Op. Cit, p.199

112. Ibid, Op. Cit, p.203

113 . Ibid p. 209

114. Merkelbach, R., Op. Cit, p. 597, fig. 125

115. Elia, O., le pitturedeltempio di Iside, MAP (III), Pompeii 3-4, 1941, figs.6-7

116. Gasmelseed, A.,"The Significance of The Palm Leaf in Merotic Religion Scenes", in: The Ninth International Conference of Nubian Studies, Museum of Fine Arts and North eastern University, Boston, 1998, p.282 
117. Bernhardt, P., Gods and Goddesses in the Garden, Greco- Roman Mythology and the Scientific Names of Plants, New Brunswick, New Jersey, and London, 2008, p. 184

${ }^{118}$. Stevenson, S., Dictionary of Roman Coins, Republication and Imperial, London,1889,p.328a

119 . Kaper, O., Temples and Gods in Roman Dakhlah,p.167

${ }^{120}$.Ayrout,H., Moeurs et Customs des Fellahs, Paris, 1983, pp.115, 153; Curmont, F., "Recherchessur le SymbolismeFuneraire des Romains" in: BAH (25), Paris, 1942, p.464, fig.99, p.477, fig.103

${ }^{121}$. Nelson, M and Janot, F., Une "Gisante" Renaissant de sesCendres, p. 376, fig. 11

122. The legend of the Egyptian saint "Onuphrius" was spread in Christian Europe, that the Palm is now the logo of the EberhardKarlsUniversität at Germany, though Europe didn't know the palm tree, it was intended by Graf Eberhard since 9. October 1474 as his university's logo to be the fountain for all the students for knowledge and Information.Wallert, I., Graf Eberhards Palme, Tübingen, 2003

123 . Dunand, F., Op. Cit, CdE (66), p. 347

${ }^{124}$. Cumont, F., Recherches sur le symbolisme funéraire des Romains, pp.482-483

125 . The stela is now in Ägyptische Staatssammlung München 11/ 147. Wallert, I., Die Palmen, pl. VII

126 . Basilios, A.," Palm Sunday", in: The Coptic Encyclopedia (4), New York, 1991, pp.1103-1104

127. Venit, M., Monumental Tombs of Ancient Alexandria, the Theater of the Dead, Cambridge, 2002, pp. 86-87, figs. 71-72. The date palm trees is appeared among an Egyptian garden up on the walls of the tomb of Sennedjem at Deir el-Medina. Shedid, A., Das Grab des Sennedjem, Ein Künstlergrab der 19. Dynastie in Deir el-Medineh, Mainz am Rhein, 1994, pp.80-81

${ }^{128}$. Venit, M., Op. Cit, pp. 89-90, fig.75, pl. IV; Brown, B., Ptolemaic Paintings and Mosaics and the Alexandrian Style, Cambridge, 1957, pls. XXVIII, XXIX

${ }_{129}$. Venit, M., The Painted Tomb from Wardian and the Decoration of Alexandrian Tombs", in: JARCE (25), 1988, p. 88, fig. 19

130 . Ibid, p. 90

131 . Griffiths, J., Op. Cit, pp. 202-203

132. Savvopoulos,K., "Alexandria in Aegypto. The Use and Meaning of Egyptian Elements in Hellenistic and Roman Alexandria", in: Isis on the Nile, pp. 81-82, fig.6. The burial place of Osiris (or the Abaton) was primarily to the west; that Bigga is a huge island in relation to Philae. Pfeiffer, S., "Die Entsprechung ägyptischer Götter im Griechischen Pantheon", in: Ägypten Griechen land Rom, p. 289. It considered containing the left leg of Osiris, which is buried there, as the source of the Nile. Bigga projected quite a bit south, thus both west and south of Philae. The Abaton, "where no one shall tead" with its primarily western orientation was fitting as the traditional direction of Osiris and the souls of the dead. But since it extended farther south, one might justifiably see it as a symbol of the Nile. Brenk, F., "Great Royal Spouse who protects Her Brother Osiris": Isis in the Isaeum at Pompeii", in: With Unperfumed Voice, pp. 353-354

133 . Junker, H., Das Götterdekret über das Abaton, in: DAWW (56/4 ), 1913, p.18

${ }^{134}$. Meyboom, P., The Nile Mosaic, p. 267

135. Venit, M., Monumental Tombs, p. 178, fig. 154

136. Hoffmann, A., "Rom und Ägypten", in: Ägyptische Gärten, p. 243, fig. 326

137. Meyboom, P., Op. Cit, pl.50; Koemoth, P., "CouronnerSouchos pour Fêter le Retour de la Crue", in: Isis on the Nile, p. 259, fig. 7

${ }^{138}$. Ibid, pl.51

139 . Ibid, pl.35; Koemoth, P., Op. Cit, p. 259, fig.2

140 . Ibid, p.92

141. Venit, M., "The Stagni Painted Tomb: Cultural and Interchange and Gender Differentiation in Roman Alexandria", in: AJA (103), 1999, pp. 661-665, figs.14,15; id., Monumental Tombs, pp.163-165, figs. 141-142

142. Venit, M.,The Tomb from Tigrane Pasha Street and the Iconography of Death in Roman Alexandria", in: AJA (101), October 1997, pp. 709-710; Grimm, G., Die RömischenMummienmaskenausÄgypten, Wiesbaden, 1974, pl. 127.2; Dunand, F., "Pratiques et Croyancesfuneraire en Egypte romaine", in: ANRW (II/ 18.5), Berlin, 1995, p. 3254; Bowman, A., Egypt after the Pharaohs, 332 BC- AD 642 from Alexander to the Arab Conquest, the University of California Press, 1986, fig. 125

143. Venit, M., Referencing Isis in Tombs of Graeco- Roman Egypt: Tradition and Innovation", in: Isis on the Nile, p. 110; Kaplan, I., Op. Cit, pp.142-132

144 . Adriani, A., Ipegodipintodella Via TigranePascia”, in: BSAA (41), 1956, p.70

145 . Brenk, F., "in the Image, Reflection and Reason of Osiris", in: With Unperfumed Voice, p.93, n.45

146. Venit, M., Monumental Tombs, pp.151-152

147. See: Venit, M.,The Tomb from Tigrane Pasha Street, pp.722-729

148 . Adriani, A., Ipegodipintodella Via TigranePascia”, in: BSAA (41), 1956, p.71

149. Venit, M., Referencing Isis , p. 109; id., Monumental Tombs, pp. 146-159, fig. 132; id., AJA (101), p. 712 , fig.7

${ }^{150}$. Venit, M., Referencing Isis, p. 109; id., Ancient Egyptomania: The Uses of Egypt in Graeco- Roman Alexandria", in: Leaving No Stones Unturned: Essays on the Ancient Near East and Egypt in Honor of Donald P. Hansen, (ed. By. Ehrenberg, E), Winona Lake, 2002,p. 276, fig.10. Adriani suggested them as Isis and Nephtys. Adriani, A., "Ipoegeodipintodella via TigrainePascia", in: BSAA (41), 1956, p.71

151 . Venit, M., Egypt as Metaphor, p. 253, fig.21.16

${ }^{152}$. Wallert, I., Graf Eberhards Palme, Tübingen, 2003, p. 130, fig. 75

153. Dils, P., Op. Cit, in: Aegyptus (70), 1990, p.83 
154. Brenk, F., Op. Cit, p. 93

155. Venit, M.,The Tomb from Tigrane Pasha Street and the Iconography of Death in Roman Alexandria", in: AJA (101), October 1997, pp.714-717; Grimm, G., Op. Cit, pl. 127.1

${ }^{156}$. Adriani suggested them as two long feathers, Adriani, A., Ipogeodipinto, p. 72, while Dils suggested that are two wreaths like two folded wreaths with ribbons hanging on them (compare with mummy portraits and masks). According to Apuleius (Met. XI.24.4) the wreath of justification was made of palm leafs. Dils,P., Op. Cit, p.83, not. 33

157. Isis gained the title as "benefactress of grain", the hymns of Isidorus from MedinetMadi celebrate the harvest in her name, the grain also was connected with her husband, Osiris, Vanderlip, V., The Four Greek Hymns of Isidorus and the Cult of Isis, Toronto, American Studies in Papyrology (12), 1972pp. 22-23, 45; Dunand, F., Le Culted'Isisdans le Bassin Oriental de la Méditerranée, Vol (1), Le Culted'Isis et le Ptolémée,Leiden: Brill, 1973, pp.219-221. Isis- Thermouthis depicted with ears of wheat. Tran, V., Le Culte des Divinitésorientales en Campanie en dehors de Pompei, de Stabies et d'Herculanum, EPRO(27), Leiden, 1972, pp.79-80, pl.6, fig.7; Venit, M., " Referencing Isis , p.112, no.107. Isis is giving wheat is found also from a tomb of a priest of Isis at Nimes. Foissy-Aufrere, M., Civilization, survivances et "Cabinet de Curiosite", Avingron, 1985, p. 151, fig.69c, a stele also in Berlin depicts Agathodaimon held a wheat. Berlin, Egyptian Museum 8164

${ }^{158}$. Diod. 1.14 .2

159 . Venit, M., "The Stagni Painted Tomb: Cultural and Interchange and Gender Differentiation in Roman Alexandria", in: AJA (103), 1999, p. 662

160. Venit, M., "Alexandria", in: The Oxford Handbook of Roman Egypt, p. 113

161. Venit, M., "Oedipus in Egypt: An Oedipus Cycle in Graeco-Roman Tuna al-Gebel," Festschrift for ZsoltKiss, Institut des cultures méditerranéennes et orientales de l'Académie Polonaise des Sciences, Études et Travaux(XXV): 2012, p. 415

162. Venit, M.,The Tomb from Tigrane Pasha Street, pp. 712-713

163 . Ibid, p.728

164. Lefebvre, G., Le Tombeau de Petosiris, TroisièmePartie, Vocabulaire et Planches, Le Caire, 1923, pl. XXV.1; Cherpion, N etal.,Le Tombeau de Petosiris a Touna el-Gebel, RelevéPhotographique, BiGen (27),Le Caire, IFAO, 2007, p.105, pl. 82

165. It wasdescribed by S. Gabra as "Maisonfunéraire 19", Gabra, S et al., Rapport sur les Fouilles d' HermoupolisOuest (Touna elGebel), Imprimerie de IFAO, Le Caire, 1941, pl. XLVIII, but itwasclassified by Grimm as home nr.20, Grimm, G., Tuna elGebel 1913-73, EineGrabung des DeutschenArchitekten W. HonrothundneuerUntersuchungen in Hermupolis-West (Tanis Superior), in: MDAIK (31), 1975.

${ }^{166}$. Gabra, S et al., Op. Cit, pp.101-102, pl. XLVIII.1; Kaplan, I., Op. Cit, p.161, pl.77 (b),78 (a).Isis appeared as a flying bird on papyrus stem upon the mummy, as the embalming scene on the east wall of first chamber of the tomb of "Petosiris". Osing, J., Denkmäler der Oase Dachla, Aus dem Nachlass von Ahmed Fakhry, A V (28), Mainz, 1982, pl. 26.b

${ }^{167}$. see Griffiths, J., The Isis-Book, p. 37

168. Gabra, S et al., Op. Cit, p. 48, pl. XVI; Kaplan, I., Op. Cit, pp. 164-165, pl. 85.b

169. Gabra, S etal., Op. Cit, pl. XII

${ }^{170}$. Osing, J., Op. Cit, p. 75, pls. 21.d, 22.a

171 . Ibid, p. 78, pl. 24.c;

172. Ibid. ,Op. Cit, p. 79, pl.24.c Lembke, K., Ägyptensspäte Blüte: die Römer am Nil, Mainz, 2004, fig. 127

173 . Ibid., Op. Cit, p.86, pl. 33 a

174 . Ibid , p. 88, pls.27, 34; Lembke, K., Op. Cit, fig. 128

175. Baum, N., Op. Cit, p. 115

176. Osing, J et al., Op. Cit, pl. 27.e; Lembke, K., Op. Cit, fig.128; Kaper, O., Isis in Roman Dakhleh: Goddess of the Village, the Province, and the Country", in: Isis on the Nile, pl. 1

177. The coffin may be from Akhmim, or Athribis, and dates back to the Ptolemaic -Roman period, in between the $2^{\text {nd }}$ half of the $1^{\text {st }}$ century BC, or the $1^{\text {st }}$ half of the $1^{\text {st }}$ century A.D, Kurth, D., MaterialienzumTotenglaubenimrömerzeitlichenÄgypten, Hützel, 2010,esp. pp. 16, 51, fig.1

178 . Venit, M., "Referencing Isis, p. 96

179. Kaper, O., Op. Cit, pp. 150-155

180. Dunand, F et al, Douch, I, la Nécropole, Exploration ArchéologiqueMonographie des tombes 1 a 72, Structures Sociales, Economiques, Religieuses de l'Egypte Romaine, IFAO, 1992, pl.59 1-2; id.,Pratiques et Croyancesfunéraire en Egypte romaine , pl. XIII.2-3

181 . Fakhry, A., Siwa Oasis, p.141, fig. 21

182. Von Bissing, F., "Tombeaux d'Epoque Romaine a Akhmim", in: ASAE(50), 1950, pp.554-573;see also , id., "Aus Römischen Gräben zu Achmim (Panopolis)in Oberägypten" , in: JDAI (61/62), 1976/1947, pp.1-16

183. Von Bissing, F., ASAE (50), p.558; id., JDAI (61/62), p.5; Kaplan, I., Op. Cit, pl.87 a

${ }^{184}$. It was classified as Tomb IV by Irene Kaplan., Op. Cit, pp. 171-173

185. Kuhlmann, K.., Materialien zur Archäologie und Geschichte des Raumes von Achmim, in :SDAIK(11), Mainz,1983, pl.37d; Kaplan, I., Op. Cit, p. 172, pl. 92 b

${ }^{186}$. Kapla,I.,Op.Cit, p. 173, pl.93(a)

${ }^{187}$. Ibid, p. 173, pl.91 (b,8); Kuhlmann, K., Op. Cit, pl. 37.c. 